\title{
Lipopolysaccharide of the Yersinia pseudotuberculosis Complex
}

\author{
Yuriy A. Knirel ${ }^{1, *}$, Andrey P. Anisimov ${ }^{2}{ }^{\circledR}$, Angelina A. Kislichkina ${ }^{2}$, Anna N. Kondakova ${ }^{1}$, Olga V. Bystrova ${ }^{1}$, \\ Anastasia S. Vagaiskaya ${ }^{2}$, Konstantin Y. Shatalin ${ }^{3}$, Alexander S. Shashkov ${ }^{1}$ and Svetlana V. Dentovskaya ${ }^{2, *}$
}

1 Laboratory of Carbohydrate Chemistry, N. D. Zelinsky Institute of Organic Chemistry, Russian Academy of Sciences, 119991 Moscow, Russia; annakond@gmail.com (A.N.K.); bystrova@interlab.ru (O.V.B.); shash@ioc.ac.ru (A.S.S.)

2 Laboratory for Plague Microbiology, Especially Dangerous Infections Department, State Research Center for Applied Microbiology and Biotechnology, 142279 Obolensk, Russia; a-p-anisimov@yandex.ru (A.P.A.); angelinakislichkina@yandex.ru (A.A.K.); vagaiskaya.anastasiya@gmail.com (A.S.V.)

3 Department of Biochemistry and Molecular Pharmacology, New York University School of Medicine, New York, NY 10016, USA; kshatalin@yahoo.com

* Correspondence: yknirel@gmail.com (Y.A.K.); dentovskaya@obolensk.org (S.V.D.); Tel.: +7-910-431-8792 (Y.A.K.); +7-916-425-0474 (S.V.D.)

check for updates

Citation: Knirel, Y.A.; Anisimov, A.P.; Kislichkina, A.A.; Kondakova, A.N.; Bystrova, O.V.; Vagaiskaya, A.S.; Shatalin, K.Y.; Shashkov, A.S.; Dentovskaya, S.V.

Lipopolysaccharide of the Yersinia pseudotuberculosis Complex. Biomolecules 2021, 11, 1410. https:// doi.org/10.3390/biom11101410

Academic Editor: Vito Verardo

Received: 12 July 2021

Accepted: 21 September 2021

Published: 26 September 2021

Publisher's Note: MDPI stays neutral with regard to jurisdictional claims in published maps and institutional affiliations.

Copyright: (c) 2021 by the authors. Licensee MDPI, Basel, Switzerland. This article is an open access article distributed under the terms and conditions of the Creative Commons Attribution (CC BY) license (https:// creativecommons.org/licenses/by/ $4.0 /)$.
Abstract: Lipopolysaccharide (LPS), localized in the outer leaflet of the outer membrane, serves as the major surface component of the Gram-negative bacterial cell envelope responsible for the activation of the host's innate immune system. Variations of the LPS structure utilized by Gramnegative bacteria promote survival by providing resistance to components of the innate immune system and preventing recognition by TLR4. This review summarizes studies of the biosynthesis of Yersinia pseudotuberculosis complex LPSs, and the roles of their structural components in molecular mechanisms of yersiniae pathogenesis and immunogenesis.

Keywords: Yersinia pseudotuberculosis; Yersinia pestis; lipopolysaccharide (LPS); lipid A; core; pathogenicity factor; pathogenesis; plague

\section{Introduction}

The lipopolysaccharide (LPS) is the major constituent of the outer leaflet of the outer membrane of Gram-negative bacteria, including the genus Yersinia. Its lipid moiety called lipid $\mathrm{A}$ is embedded in the membrane and serves as an anchor for the rest of the LPS molecule. The S (smooth)-form LPS possesses an outermost repetitive glycan region designated as the O-specific polysaccharide (O-polysaccharide, OPS) as it defines the serospecificity of the bacteria and, therefore, is often called O-antigen. The OPS is linked to lipid A via a negatively charged oligosaccharide called core. Both the lipid A and core are important for the integrity and regulation of the permeability of the outer membrane. The $\mathrm{R}$ (rough)-form LPS is limited to the core and lipid moieties. The OPS is a highly variable portion of the LPS and is used as the basis for bacterial O-serotyping. It also provides protection to the microorganisms from host defense mechanisms, such as complementmediated killing and phagocytosis.

Currently, the genus Yersinia comprises 27 species, of which several species, including Yersinia pseudotuberculosis / Yersinia pestis, Yersinia similis and Yersinia wautersii (or the Korean group of strains), are combined into the so-called Y.pseudotuberculosis complex. Except for Yersinia pestis, which has an R-form LPS, the other members of the Y.pseudotuberculosis complex are able to produce an S-form LPS. Recent advances in chemical analytical methods, spectrometry and whole-genome sequencing have made it possible to determine the spectra of polymorphisms of fine structures of the constituent components of Yersinia molecules and to begin to determine the functional significance of individual elements of this polyfunctional molecule. This review focuses on recent studies of the 
LPS structure and genetics of biosynthesis of these molecules and discusses the relationship between the LPS molecular structure and the virulence of the representatives of the Y. pseudotuberculosis complex.

\section{Y. pestis and Y. pseudotuberculosis Lipopolysaccharide Structures}

2.1. Composition and Structure of the O-Specific Polysaccharides

Currently, the O-serotyping scheme of Y. pseudotuberculosis [1], which may also be applied to the other species of the complex [2,3], includes 21 O-serotypes, of which, only 18 have been validated as the $\mathrm{O}$-antigen-based serotypes. The other three, $\mathrm{O} 8, \mathrm{O} 13$ and O14, are expressed by rough mutants and define no O-specificity. Therefore, they must be excluded from the O-serotyping scheme [4].

Smooth strains of $Y$. pseudotuberculosis have branched regular OPSs made up of tetraor penta-saccharide $\mathrm{O}$ units with a di- to tetra-saccharide repeat in the main chain and a mono- or di-saccharide side chain(s) (Table 1). The OPSs are synthesized by the polymerasedependent pathway, which includes the assembly of the $\mathrm{O}$ unit on a lipid carrier at the periplasmic side of the inner membrane followed by polymerization. Either 2-acetamido-2deoxyglucose (GlcNAc) or 2-acetamido-2-deoxygalactose (GalNAc) has been demonstrated to be the first monosaccharide of the $\mathrm{O}$ unit [5], whose transfer to the lipid carrier initiates the synthesis of the serotypes O4b and O3 OPSs, respectively. Genetic data suggest that an amino sugar (GlcNAc or GalNAc) is the first in the $\mathrm{O}$ units of the other O-serotypes too, as shown in Table 1.

In most O-serotypes, main-chain components are rather common monosaccharides, such as D-Glc, D-Gal, D-Man, L-Fuc, D-GlcNAc and D-GalNAc, which all exist in the pyranose form. The exceptions are the OPSs of serotypes O12 and O9, which contain rarely occurring deoxy sugars, 6-deoxy-L-glucose (L-Qui) and N-acetimidoylamino-2,6dideoxy-L-galactose (L-FucNAm), respectively, in the main chain. The latter is the only acidic OPS of Y. pseudotuberculosis due to the presence of 3-O-acetylated 2-acetamido-2deoxy-D-glucuronic acid (D-GlcNAcA).

In contrast to the main chains, the side chains in most OPSs are composed of unusual monosaccharides, such as 3,6-dideoxyhexoses, including abequose (Abe), ascarylose (Asc), colitose (Col) and tyvelose (Tyv), which are always pyranosidic, as well as paratose (Par), which occurs as either a pyranoside or furanoside. Abequose with a 1-hydroxyethyl side chain called yersiniose A (Yer) occurs in the OPSs of serotypes O6 and O12. Two more unusual side-chain deoxy sugars, 6-deoxy-L-altrose in the furanose form and 6deoxy-D-manno-heptose (6dmanHep) in the pyranose form, are present in the OPSs of several O-serotypes. The OPSs of serotypes O6 and O7 exceptionally bear a D-glucose or D-galactose side chain, respectively.

It is worth noting that the O-antigen expression by $Y$. pseudotubrculosis is downregulated at $37^{\circ} \mathrm{C}$, resulting in the production of predominantly SR-form LPS, in which the OPS is limited to the single O-unit $[5,6]$. Various minor modifications are observed to the $\mathrm{O}$ unit in the SR-form LPS. When the synthesis of 6dmanHep is impaired, its biosynthetic precursor, D-glycero-D-manno-heptose, is incorporated into the O-unit of Y. pseudotuberculosis O2a in place of 6dmanHep [7]. Minor hexosylation (presumably glucosylation) of the $\mathrm{O}$ unit occurs in the SR-form LPS of Y. pseudotuberculosis O3 [5].

Many OPSs of $Y$. pseudotuberculosis are structurally and, as a result, serologically related due to the presence of the same lateral monosaccharide, e.g., $\beta$-Parf, $\alpha$-Abe $p$ or $\alpha$-Tyv $p$ in serotypes O1, O2 and O4, respectively, or $\alpha$-Col, in serotypes O6, O7 and O10. Some other OPS groups (those of serotypes O1a, O2a and $\mathrm{O} 4 \mathrm{~b} ; \mathrm{O} 1 \mathrm{c}, \mathrm{O} 2 \mathrm{~b}$ and $\mathrm{O} 3 ; \mathrm{O} 1 \mathrm{~b}$ and $\mathrm{O} 11 ; \mathrm{O} 2 \mathrm{c}$ and $\mathrm{O} 4 \mathrm{a} ; \mathrm{O} 5 \mathrm{a}, \mathrm{O} 5 \mathrm{~b}$ and $\mathrm{O} 15$ ) share their main chain structure.

Although most OPS structures are unique to Y. pseudotuberculosis, there are two exceptions. The OPS of serotype O10 is closely related to that shared by Escherichia coli O111 and Salmonella enterica O35 [8,9], both differing in the presence of a D-GalNAc residue in the main chain in place of a D-GlcNAc residue. The main chain of the OPSs of Y. pseudotuberculosis O2c and O4a is identical to the linear OPS of S. enterica O18 [10]. 
Table 1. Structures of the O-specific polysaccharides of Y.pseudotuberculosis.

\begin{tabular}{|c|c|}
\hline Serotype [Reference] & Structure of the Repeating Unit \\
\hline $\begin{aligned} \text { O1a R } & =\beta-\operatorname{Par} f[11] \\
\text { O2a R } & =\alpha-\operatorname{Abe} p[7] \\
\text { O4b R } & =\alpha-\operatorname{Tyv} p[12]\end{aligned}$ & $\begin{array}{c}\rightarrow 3)-\alpha-\mathrm{D}-\mathrm{Gal} p-(1 \rightarrow 3)-\beta-\mathrm{D}-\mathrm{Glc} p \mathrm{NAc}-(1 \rightarrow \\
4 \\
\uparrow \\
1 \\
\mathrm{R}-(1 \rightarrow 3)-\beta-\mathrm{D}-6 \mathrm{dmanHep} p\end{array}$ \\
\hline $\begin{aligned} \mathrm{O} 1 \mathrm{c} \mathrm{R} & =\beta-\operatorname{Parf}[13] \\
\mathrm{O} 2 \mathrm{~b} \mathrm{R} & =\alpha-\text {-Abep }[14]\end{aligned}$ & $\begin{array}{l}\rightarrow 2)-\alpha-\mathrm{D}-\mathrm{Man} p-(1 \rightarrow 3)-\alpha-\mathrm{L}-\mathrm{Fuc} p-(1 \rightarrow 3)-\beta-\mathrm{D}-\mathrm{Gal} p \mathrm{NAc}-(1 \rightarrow \\
3 \\
\uparrow \\
1 \\
\mathrm{R}\end{array}$ \\
\hline O3 [15] & $\begin{array}{c}\rightarrow 2)-\alpha \text {-D-Man } p-(1 \rightarrow 3)-\alpha-\mathrm{D}-\mathrm{Man} p-(1 \rightarrow 3)-\beta-\mathrm{D}-\mathrm{Gal} p \mathrm{NAc}-(1 \rightarrow \\
4 \\
\uparrow \\
1 \\
\beta-P a r p\end{array}$ \\
\hline $\begin{array}{l}\text { O2c R }=\alpha \text {-Abe } p[15] \\
\text { O4a R }=\alpha \text {-Tyv } p[16]\end{array}$ & $\begin{array}{l}\rightarrow 6)-\beta \text {-D-Man } p-(1 \rightarrow 6)-\alpha-\mathrm{D}-\mathrm{Man} p-(1 \rightarrow 2)-\beta-\mathrm{D}-\mathrm{Man} p-(1 \rightarrow 3)-\beta \text {-D-Gal } p \mathrm{NAc}-(1 \rightarrow \\
3 \\
\uparrow \\
1 \\
\mathrm{R}\end{array}$ \\
\hline $\begin{array}{c}\text { O1b R }=\beta-P a r f ~[17] \\
\text { O11 R }=\alpha \text {-L-6dAltf [18] }\end{array}$ & $\begin{array}{l}\rightarrow 2)-\beta \text {-D-Man } p-(1 \rightarrow 4)-\alpha-\mathrm{D}-\mathrm{Man} p-(1 \rightarrow 3)-\alpha-\mathrm{L}-\mathrm{Fuc} p-(1 \rightarrow 3)-\beta-\mathrm{D}-\mathrm{Glc} p \mathrm{NAc}-(1 \rightarrow \\
3 \\
\uparrow \\
1 \\
\mathrm{R}\end{array}$ \\
\hline $\begin{array}{c}\text { O5a R }=\alpha-\operatorname{Asc} p[19] \\
\text { O5b R }=\alpha \text {-L-6dAltf [20] } \\
\text { O15 R }=\beta-\text {-Parf [21] }\end{array}$ & $\begin{array}{l}\rightarrow 2)-\alpha-L-F u c p-(1 \rightarrow 3)-\alpha-D-M a n p-(1 \rightarrow 4)-\alpha-L-F u c p-(1 \rightarrow 3)-\beta-D-G a 1 p N A c-(1 \rightarrow \\
3 \\
\uparrow \\
1 \\
\quad R\end{array}$ \\
\hline O6 [22,23] & $\begin{array}{c}\rightarrow 3)-\beta-D-G l c p N A c-(1 \rightarrow 6)-\alpha-D-G a l p N A c-(1 \rightarrow 3)-\beta-D-G a l p N A c-(1 \rightarrow \\
3 \\
\uparrow \\
1 \\
\alpha-C o l p-(1 \rightarrow 2)-\beta-\text { Yer } p\end{array}$ \\
\hline O7 [24] & $\begin{array}{cc}\rightarrow 6)-\beta-\mathrm{D}-\mathrm{Glc} p-(1 \rightarrow 3)-\alpha-\mathrm{D}-\mathrm{Gal} p \text { NAc- }(1 \rightarrow 3)-\beta-\mathrm{D}-\mathrm{Gal} p \mathrm{NAc}-(1 \rightarrow \\
2 & 6 \\
\uparrow & \uparrow \\
1 & 1 \\
\alpha \text {-Col } p & \alpha-\mathrm{D}-\mathrm{Glc} p\end{array}$ \\
\hline
\end{tabular}


Table 1. Cont.

\begin{tabular}{|c|c|}
\hline Serotype [Reference] & Structure of the Repeating Unit \\
\hline $\mathrm{O} 10$ [25] & $\begin{array}{c}\alpha-\mathrm{Col} p \\
1 \\
\downarrow \\
3 \\
\rightarrow 4)-\alpha-\mathrm{D}-\mathrm{Glc} p-(1 \rightarrow 4)-\alpha-\mathrm{D}-\mathrm{Gal} p-(1 \rightarrow 3)-\beta-\mathrm{D}-\mathrm{Gal} p \mathrm{NAc}-(1 \rightarrow \\
6 \\
\uparrow \\
1 \\
\alpha \text {-Col } p\end{array}$ \\
\hline O12 [3] & $\begin{array}{c}\rightarrow 3)-\alpha-\mathrm{D}-\mathrm{Gal} p-(1 \rightarrow 4)-\alpha-\mathrm{L}-\mathrm{Qui} p-(1 \rightarrow 3)-\beta-\mathrm{D}-\mathrm{Glc} p \text { NAc- }(1 \rightarrow \\
4 \\
\uparrow \\
1 \\
\beta-Y e r p\end{array}$ \\
\hline O9 $[26,27]$ & $\begin{array}{cc}\rightarrow 4)-\alpha-\mathrm{D}-\mathrm{Glc} p \mathrm{NAcA}-(1 \rightarrow 4)-\alpha-\mathrm{L}-\mathrm{Fuc} p \mathrm{NAm}-(1 \rightarrow 3)-\alpha-\mathrm{D}-\mathrm{Glc} p \mathrm{NAc}-(1 \rightarrow \\
3 & 3 \\
\mid & \uparrow \\
\text { OAc } & 1 \\
& \alpha-\mathrm{D}-\mathrm{Gal} p\end{array}$ \\
\hline
\end{tabular}

\subsection{Structural Variants of the Core Region}

The structure of the inner core consisting of two residues of oct-2-ulosonic acids (Kdo or Ko) and three residues of L-glycero-D-manno-heptose (Hep) is conserved in the Enterobacteriales order, including the genus Yersinia.

The first heptose residue linked to Kdo carries a $\beta$-D-Glc residue, which is characteristic of the so-called non-Salmonella core type (Table 2). In the R-form LPS of Y. pseudotuberculosis and LPS of $Y$. pestis, a $\beta$-D-GlcNAc residue is present at position three of the second heptose residue in a non-stoichiometric amount. This position is the site of attachment of a longchain OPS or a single O unit in the S- and SR-form LPS of Y. pseudotuberculosis, respectively.

When $Y$. pestis ssp. pestis, the main subspecies of $Y$. pestis, is cultivated at $37^{\circ} \mathrm{C}$, which mimics the condition in not hibernating mammals, position seven of the third heptose residue is occupied by a residue of D-glycero-D-manno-heptose (DD-Hep) (Table 2). The cultivation of bacteria at lower temperatures resulted in two significant changes in the core, including the replacement of DD-Hep with D-Gal and 3-hydroxylation of the sidechain Kdo residue to afford a Ko residue [5,28] (Table 2). Almost full replacement is observed at $6{ }^{\circ} \mathrm{C}$, whereas at $25^{\circ} \mathrm{C}$, mainly mixed core glycoforms, DD-Hep+Ko and D-Gal+Kdo, are produced. A similar temperature-dependent alternation of these two pairs of the lateral monosaccharides also occurs in the core of $Y$. pseudotuberculosis [5]. A significant distinction of $Y$. pestis ssp. microti bvv. caucasica and altaica is the inability to incorporate DD-Hep into the core at any temperatures [5] (Table 2). 
Table 2. Structures of the core oligosaccharides of Y. pseudotuberculosis/Y. pestis cultivated at various temperatures. Substituents present in non-stoichiometric amounts are indicated in italics.

\begin{tabular}{|c|c|c|c|}
\hline \multirow[t]{2}{*}{ Species, Growth Temperature [Reference] } & \multicolumn{3}{|c|}{ Major Structure } \\
\hline & \multicolumn{3}{|c|}{$\beta-D-G l c p N A c-(1 \rightarrow 3)-\alpha-\operatorname{Hep} p-(1 \rightarrow 3)-\alpha-\operatorname{Hep} p-(1 \rightarrow 3)-\alpha-\operatorname{Kdo} p-(2 \rightarrow$} \\
\hline Y.pseudotuberculosis/Y. pestis ssp. pestis & 7 & 4 & 4 \\
\hline $\begin{array}{l}\text { 1. pseudotuberculosis } / \text { Y. pestis ssp. pestis } \\
\qquad 37^{\circ} \mathrm{C}[28]\end{array}$ & $\uparrow$ & $\uparrow$ & $\uparrow$ \\
\hline \multirow[t]{2}{*}{ LPS-37 } & 1 & 1 & 2 \\
\hline & D- $\alpha-\mathrm{D}-\mathrm{Hep} p-(1 \rightarrow 7)-\alpha-\mathrm{Hep} p$ & $\beta$-D-Gle $p$ & $\alpha-\mathrm{Kdo} p$ \\
\hline & \multicolumn{3}{|c|}{$\beta-D-G l c p N A c-(1 \rightarrow 3)-\alpha-\operatorname{Hep} p-(1 \rightarrow 3)-\alpha-\operatorname{Hep} p-(1 \rightarrow 3)-\alpha-\mathrm{Kdo} p-(2 \rightarrow$} \\
\hline Y. pestis ssp. microti bvv. caucasica, altaica & 7 & 4 & 4 \\
\hline $37^{\circ} \mathrm{C}[5]$ & $\uparrow$ & $\uparrow$ & $\uparrow$ \\
\hline \multirow[t]{3}{*}{ LPS-37 } & 1 & 1 & 2 \\
\hline & $\alpha-\operatorname{Hep} p$ & $\beta$-D-Glc $p$ & $\alpha-\mathrm{Kdo} p$ \\
\hline & \multicolumn{3}{|c|}{$\beta$-D-GlcpNAc- $(1 \rightarrow 3)-\alpha-\operatorname{Hep} p-(1 \rightarrow 3)-\alpha-\operatorname{Hep} p-(1 \rightarrow 3)-\alpha-\mathrm{Kdo} p-(2 \rightarrow$} \\
\hline Y.pseudotuberculosis/Y. pestis ssp. pestis & 7 & 4 & 4 \\
\hline $25^{\circ} \mathrm{C}[28]$ & $\uparrow$ & $\uparrow$ & $\uparrow$ \\
\hline \multirow[t]{2}{*}{ LPS-25 } & 1 & 1 & 2 \\
\hline & $\alpha-\mathrm{D}-\mathrm{Gal} p-(1 \rightarrow 7)-\alpha-\mathrm{Hep} p$ & $\beta-\mathrm{D}-\mathrm{Gl} p p$ & $\alpha-\mathrm{Kop}$ \\
\hline & \multicolumn{3}{|c|}{$\beta-D$-GlcpNAc- $(1 \rightarrow 3)-\alpha-\operatorname{Hep} p-(1 \rightarrow 3)-\alpha-\operatorname{Hep} p-(1 \rightarrow 3)-\alpha-K d o p-(2 \rightarrow$} \\
\hline & 7 & 4 & 4 \\
\hline $\begin{array}{l}\text { Y. pestls ssp. pestls } \\
6^{\circ} \mathrm{C}[29]\end{array}$ & $\uparrow$ & $\uparrow$ & $\uparrow$ \\
\hline \multirow[t]{2}{*}{ LPS-6 } & 1 & 1 & 2 \\
\hline & D- $\alpha-\mathrm{D}-\mathrm{Hep} p-(1 \rightarrow 7)-\alpha-\mathrm{Hep} p$ & $\beta$-D-Glep & $\alpha-\mathrm{Ko} p-7-P E t N$ \\
\hline
\end{tabular}

The incorporation of Gal into the core, but not the hydroxylation of Kdo, is under the control of the two-component PhoPQ signal transduction system [30].

The content of GlcNAc increases, and that of the glycine present at an unknown position in the core of $Y$. pestis decreases with a growth temperature elevation $[5,31]$.

When cultivated at $6{ }^{\circ} \mathrm{C}$, Y. pestis also produces another LPS variant, which is distinguished by the phosphorylation of the Ko (major) or Kdo (minor) residue with 2-aminoethyl phosphate (PEtN) combined with the presence of DD-Hep [29] (Table 2). Minor PEtN is also present at $25^{\circ} \mathrm{C}$ on the Ko residue in the core of $Y$. pestis bv. altaica but not ssp. pestis.

\subsection{Structure Variations of Lipid A}

As with that of the core, the lipid A structure of Y. pestis was studied in detail. At $25{ }^{\circ} \mathrm{C}$, the bacteria produce a hexaacylated bisphosphorylated lipid A species containing four primary 3-hydroxymyristoyl (3HO14:0) groups and secondary lauroyl 12:0 and palmitoleoyl 16:1 groups. Each of the phosphate groups carries a 4-amino-4-deoxy-L-arabinose (Ara4N) residue (Figure 1A). This hexaacyl lipid A is accompanied by a pentaacyl species that lacks the 16:1 group (Figure 1B) and a tetraacyl species that is devoid of both secondary acyl groups (Figure 1C).

An alternative pentaacylated lipid A that is distinguished by the presence of four primary 3HO14:0 groups and the secondary 16:1 group (Figure 1D), occurs in $Y$. pestis cultivated at $6^{\circ} \mathrm{C}[29]$. Remarkably, at this temperature, Ara $4 \mathrm{~N}$ is absent from some lipid A species [29].

Upon cultivation at an elevated temperature, the acylation degree and the content of Ara4N significantly decrease so that at $37^{\circ} \mathrm{C}$, the lipid A of $Y$. pestis consists mainly of tetraacyl species with four primary $3 \mathrm{HO} 14: 0$ groups and non-glycosylated phosphate groups. There are also minor triacyl species and those containing a diphosphate group. 
A
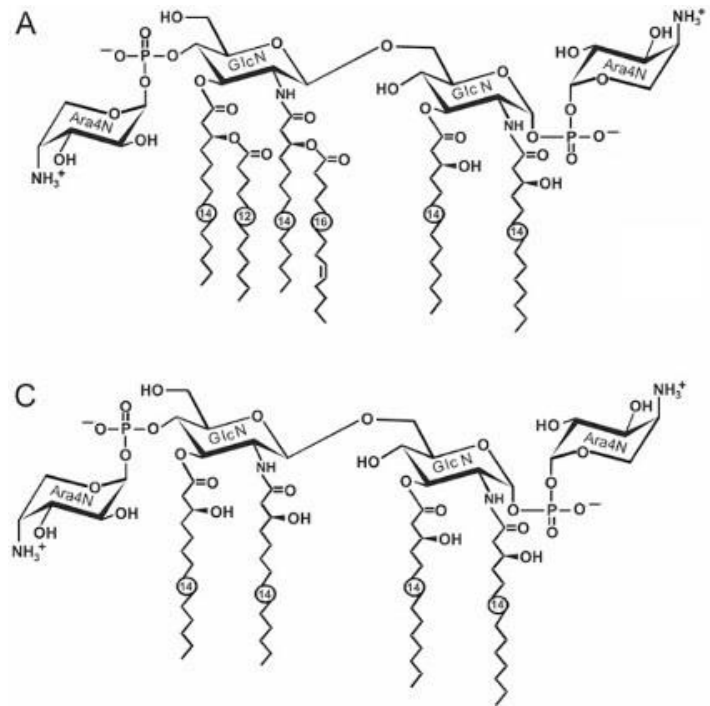

B
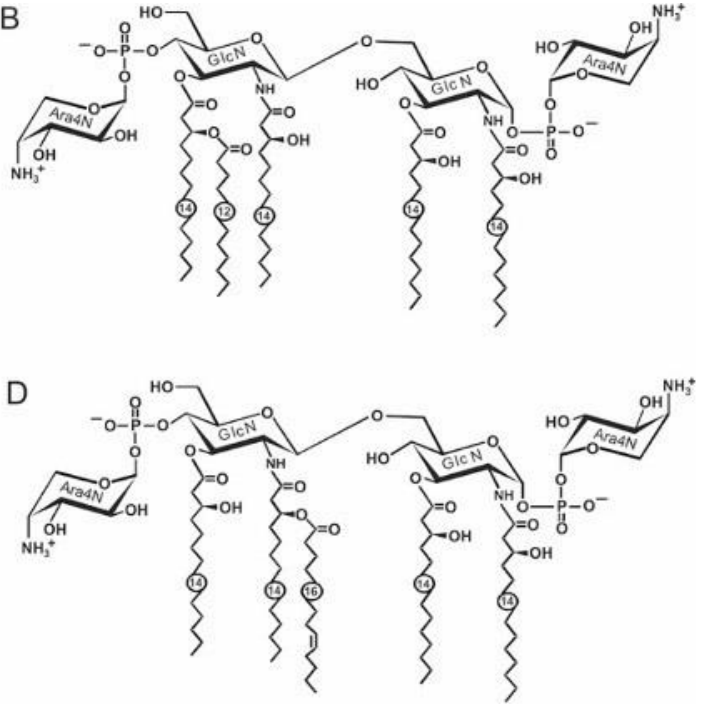

Figure 1. Structures of hexaacyl (A), pentaacyl (B) and tetraacyl (C,D) lipid A species of Y. pestis and Y.pseudotuberculosis. In tetraacyl lipid A of $Y$. pestis (C,D), Ara $4 \mathrm{~N}$ is present in a non-stoichiometric amount at $37^{\circ}$ or completely absent at $6{ }^{\circ} \mathrm{C}$, respectively.

At $37^{\circ} \mathrm{C}$, lipid A of Y.pseudotuberculosis lacks diphosphate-containing species, and the content of Ara $4 \mathrm{~N}$ is significantly higher than in Y.pestis. This lipid A is distinguished by the presence in some species of a secondary 16:0 acyl group [5,32,33].

\section{Genetics and Biosynthesis}

The biosynthesis of lipid A has been studied in detail for enteric bacteria [34], particularly E. coli, and this pathway is assumed to be generally conserved in members of the $Y$. pseudotuberculosis complex. The pathway is mediated by nine enzymes (Table 3) and located in the cytoplasm and on the inner surface of inner membrane. All of the corresponding homologous genes encoding enzymes required for the biosynthesis of the biphosphorylated precursor of enterobacterial lipid A (lipid $\mathrm{IV}_{\mathrm{A}}$ ) structure (including the primary acyltransferases LpxA and LpxD, the deacetylase $L p x C$, the nucleotidase $L p x H$, the disaccharide synthase $\mathrm{LpxB}$ and the kinase LpxK) were identified in the genome of Y. pestis (Table 3). The minimal LPS structure needed for the viability of Y. pestis is lipid $\mathrm{IV}_{\mathrm{A}}$, although such $Y$. pestis mutants exhibit highly attenuated growth [35].

Different forms of lipid A could then be synthesized and modified from lipid $I_{\mathrm{A}}$ by different enzymes depending on the environmental conditions. "Late" acyltransferases responsible for attaching secondary acyl substituents, such as myristoyl and palmitoleyl, are encoded by $Y$. pestis I $x M$ and lpxP genes, respectively. The Y. pestis LpxM and LpxP transfer laurate and palmitoleate to 3-hydroxymyristate residues at positions $3^{\prime}$ and $2^{\prime}$ GlcNII, respectively. E. coli gene coding for secondary acyltransferase LpxL (HtrB) has not been identified in the $Y$. pestis genome. As with E. coli, the addition of the first core sugar 3-deoxy-D-manno-oct-2-ulosonic acid (Kdo) to the lipid $\mathrm{IV}_{\mathrm{A}}$ is strictly necessary for the attachment of the secondary acyl groups in Y. pestis [35-38]. Their expression level increases as the cultivation temperature decreases from 37 to $21^{\circ} \mathrm{C}$. The mutant at both genes synthesizes tetraacyl lipid A, which is similar to lipid $\operatorname{IV}_{\mathrm{A}}$ (Figure $1 \mathrm{C}$ ) and identical to that synthesized by wild-type $Y$. pestis strains at $37^{\circ} \mathrm{C}$ [37]. Kdo-independent late acylation in the lipid A has been shown in E. coli under slow growth conditions at low temperatures or upon the overexpression of genes encoding late-acyl transferases [39-41]. 
Table 3. Homologues of Y. pestis lipid A biosynthesis and structural modification genes found in the Y. pseudotuberculosis/E. coli genomes. Sequence conservation relates to alignments with the Y. pseudotuberculosis IP 32953 and E. coli K-12 sequences.

\begin{tabular}{|c|c|c|}
\hline $\begin{array}{c}\text { Gene } \\
\text { Y. pestis CO92 }\end{array}$ & $\begin{array}{c}\text { Related Proteins } \\
\text { (\% identity Y.pseudotuberculosis/E. coli) }\end{array}$ & Proposed Function \\
\hline \multicolumn{3}{|c|}{ Biosynthesis } \\
\hline $\operatorname{lp} x A / \mathrm{YPO} 1056$ & $\begin{array}{c}100 \% \text { Y. pseudotuberculosis CAH22229.1/82\% E. coli } \\
\text { BAA77856.2 }\end{array}$ & $\begin{array}{l}\text { UDP-N-acetylglucosamine } \\
\text { acetyltransferase }\end{array}$ \\
\hline $\operatorname{lpxC/YPO0561~}$ & $\begin{array}{l}\text { 100\% Y. pseudotuberculosis CAH19934.1/93\% E. coli } \\
\text { NP_414638.1 }\end{array}$ & $\begin{array}{l}\text { UDP-3-O-acyl-N-acetylglucosamine } \\
\text { deacetylase }\end{array}$ \\
\hline $\operatorname{lp} x D /$ YPO1054 & $\begin{array}{l}\text { 100\% Y.pseudotuberculosis CAH22231.1/83\% E. coli } \\
\text { NP_414721.1 }\end{array}$ & $\begin{array}{c}\text { UDP-3-O-(3- } \\
\text { hydroxymyristoyl)glucosamine } \\
\text { N-acyltransferase }\end{array}$ \\
\hline $\operatorname{lp} x H / Y P O 3075$ & $\begin{array}{l}\text { 100\% Y.pseudotuberculosis CAH22231.1/70\% E. coli } \\
\text { NP_415057.1 }\end{array}$ & $\begin{array}{l}\text { UDP-2,3-diacylglucosamine } \\
\text { diphosphatase }\end{array}$ \\
\hline $\operatorname{lp} x B / Y P O 1057$ & $\begin{array}{l}\text { 100\% Y. pseudotuberculosis CAH20273.1/82\% E. coli } \\
\text { NP_414724.1 }\end{array}$ & Lipid A disaccharide synthase \\
\hline lpxK/YPO1396 & $\begin{array}{l}\text { 100\% Y.pseudotuberculosis CAH20661.1/70\% E. coli } \\
\text { NP_415435.1 }\end{array}$ & Tetraacyldisaccharide $4^{\prime}$-kinase \\
\hline waaA $(k d t A) / Y P O 0055$ & $\begin{array}{l}\text { 100\% Y.pseudotuberculosis CAH19292.1/80\% E. coli } \\
\text { NP_418090.1 }\end{array}$ & Kdo transferase \\
\hline $\operatorname{lp} x M / Y P O 2063$ & $\begin{array}{l}\text { 100\% Y. pseudotuberculosis CAH21284.1/65\% E. coli } \\
\text { NP_416369.1 }\end{array}$ & Lauroyl acyltransferase \\
\hline lpxP/YPO3632 & $\begin{array}{l}\text { 100\% Y.pseudotuberculosis CAH22835.1/67\% E. coli } \\
\text { NP_416879.4 }\end{array}$ & Palmitoleoyl acyltransferase \\
\hline \multicolumn{3}{|c|}{ Structural Modification } \\
\hline pagP/YPO1744 & $\begin{array}{l}\text { 100\% Y.pseudotuberculosis CAH20861.1/53\% E. coli } \\
\text { NP_415155.1 }\end{array}$ & Palmitoyltransferase acyltransferase \\
\hline $\operatorname{arnT/YPO2418~}$ & $\begin{array}{c}\text { 100\% Y.pseudotuberculosis CAH21564.1/54\% E. coli } \\
\text { ArnT NP_416760.1 }\end{array}$ & $\begin{array}{l}\text { Lipid } \mathrm{IV}_{\mathrm{A}} \text { 4-amino-4-deoxy-L- } \\
\quad \text { arabinosyltransferase }\end{array}$ \\
\hline lpxT (yeiU)/YPO1276 & $\begin{array}{l}\text { 99\% Y.pseudotuberculosis CAH20550.1/62\% E. coli } \\
\text { NP_416679.4 }\end{array}$ & $\mathrm{Kdo}_{2}$-lipid A phosphotransferase \\
\hline
\end{tabular}

The outer membrane palmitoyl transferase protein PagP was originally identified in Salmonella and is responsible for the addition of the secondary 16:0 acyl group (palmitate) to lipid A [42]. PagP activity provides resistance to certain CAMPs; presumably, increased acyl-chain packing prevents the translocation of CAMPs across the outer membrane [42]. The addition of a palmitate to lipid A by enzyme PagP also occurs in immunostimulatory $Y$. pseudotubrculosis and Y. enterocolitica strains, but not in immune-evasive $Y$. pestis $[5,32,43]$. The analysis of $Y$. pestis pagP gene sequences identified a single-nucleotide polymorphism that results in a premature stop in translation, yielding a truncated, non-functional enzyme [36].

ArnT is an amino-arabinose transferase that transfers L-Arn $4 \mathrm{~N}$ to the $4^{\prime}$-phosphate of lipid A. The biosynthesis pathway of aminoarabinose and its addition to lipid A has been well characterized in E. coli and S. enterica (reviewed by Trent [44] and Bishop [36]). A complete inner core (Kdo, HepI, HepII, Glc and HepIII) is required to ensure the most efficient incorporation of Ara4N, whereas the presence or absence of core monosaccharides distal from lipid A (GlcNAc, Gal and DD-Hep) has no effect on this process [35,45,46]. As in E. coli and S. enterica, it was found that the arn operon in Y. pestis is regulated by two-component signal transduction systems, PhoP/PhoQ and PmrA/PmrB [32,47].

A homologous gene of phosphatase LpxT (YeiU) transferring phosphate from UndPP to lipid A giving rise to diphosphate has also been found in the genome of $Y$. pestis [35,42]. 
The core biosynthesis genes in E. coli, S. enterica and a number of other enterobacteria are clustered in a chromosomal region, forming the waa cluster [34]. Two clusters (waaI and waaII) with four and two homologues of the waa genes and one cluster with two wab genes, which also encode core biosynthetic enzymes, have been identified in the $Y$. pestis genome $[35,45,46]$. The respective function of each of these proteins (either demonstrated or proposed based on homology comparisons) has been summarized (Table 4).

Table 4. Homologues of $Y$. pestis core OS biosynthesis genes found in the Y. pseudotuberculosis / E. coli genomes. Sequence conservation relates to alignments with the Y. pseudotuberculosis IP 32953 and E. coli K-12 sequences [35,48-50].

\begin{tabular}{|c|c|c|}
\hline $\begin{array}{c}\text { Gene } \\
\text { Y. pestis CO92 }\end{array}$ & $\begin{array}{c}\text { Related Proteins } \\
\text { (\% Identity } Y . \text { pseudotuberculosis/E. coli) }\end{array}$ & Proposed Function \\
\hline \multicolumn{3}{|c|}{ CORE BIOSYNTHESIS GENE CLUSTER waaI } \\
\hline gmhD/YPO0058 & $\begin{array}{l}\text { 100\% Y.pseudotuberculosis CAH19295.1/83\% E. coli } \\
\text { BAE77673.1 }\end{array}$ & ADP-L,D-Heptose epimerase \\
\hline waaF/YPO0057 & $\begin{array}{l}\text { 99\% Y.pseudotuberculosis CAH19294.1/74\% E. coli } \\
\text { NP_418077.1 }\end{array}$ & Heptosyltransferase (HepI) \\
\hline waaC/YPO0056 & $\begin{array}{l}\text { 100\% Y.pseudotuberculosis CAH19293.1/68\% E. coli } \\
\text { NP_418078.1 }\end{array}$ & Heptosyltransferase (HepII) \\
\hline waaA/YPO0055 & $\begin{array}{l}\text { 100\% Y. pseudotuberculosis CAH19292.1/80\% E. coli } \\
\text { NP_418090.1 }\end{array}$ & Kdo-transferase (KdoI, KdoII) \\
\hline waaE/YPO054 & $\begin{array}{l}\text { 100\% Y.pseudotuberculosis CAH19291.1/76\% } \\
\text { Serratia marcescens AAC44433.1 }\end{array}$ & Glycosyltransferase (Glc) \\
\hline \multicolumn{3}{|c|}{ CORE BIOSYNTHESIS GENE CLUSTER $w a b$} \\
\hline wabC/YPO0186 & $\begin{array}{c}99 \% \text { Y.pseudotuberculosis CAH22956.1/61\% } \\
\text { Burkholderia pyrrocinia PXX29563.1 }\end{array}$ & Heptosyltransferase (HepIV) \\
\hline wabD/YPO0187 & $\begin{array}{c}99 \% \text { Y. pseudotuberculosis CAH22955.1/44\% Proteus } \\
\text { mirabilis MBG3081359.1 }\end{array}$ & Glycosyltransferase (Gal) \\
\hline \multicolumn{3}{|c|}{ CORE BIOSYNTHESIS GENE CLUSTER waaII } \\
\hline waaQ/YPO0416 & $\begin{array}{l}\text { 99\% Y.pseudotuberculosis CAH19795.1/40\% E. coli } \\
\text { NP_418089.1 }\end{array}$ & Heptosyltransferase (HepIII) \\
\hline waaL/YPO0417 & $\begin{array}{l}\text { 100\% Y.pseudotuberculosis CAH19796.1/59\% } \\
\text { Serratia fonticola WP_074031921.1 }\end{array}$ & O-antigen ligase \\
\hline \multicolumn{3}{|c|}{ structural modification } \\
\hline eptB/YPO4013 & $\begin{array}{l}\text { 99\% Y.pseudotuberculosis CAH23086.1/63\% E. coli } \\
\text { NP_418002.2 }\end{array}$ & $\begin{array}{l}\mathrm{Kdo}_{2} \text {-lipid A phosphoethanolamine } \\
\text { 7"-transferase }\end{array}$ \\
\hline$k d o O / Y P O 1650$ & $\begin{array}{c}\text { 99\% Y.pseudotuberculosis CAH21657.1/69\% Serratia } \\
\text { marcescens ASL83593.1 }\end{array}$ & Kdo-3-hydroxylase \\
\hline
\end{tabular}

In Y. pseudotuberculosis $Y$. pestis, the waaI cluster contains five genes gmhD-waaF-waaCwaaA-waaE that are required for the biosynthesis of inner core oligosaccharides (Table 4). The $g m h D, w a a C$ and waaF genes encode proteins involved in the biosynthesis and transfer of HepI and HepII, whereas the waaE gene is responsible for transferring a Glc residue to the HepI residue in the core. The gene waaA encodes WaaA that can add one or two Kdo residues to the lipid $\mathrm{IV}_{\mathrm{A}}$. The $w a b$ cluster contains two genes that code for enzymes that are responsible for the biosynthesis of outer core oligosaccharides. The waaII cluster contains two genes, waaQ and waaL. The waaL gene encodes a ligase enzyme required for the attachment of O-antigen to the core-lipid A. The heptosyltransferase WaaQ adds a HepIII residue to the HepII [35].

As mentioned above, the terminal Kdo residue in the core at a low temperature is partially substituted for the Ko residue. The latter is synthesized via the oxidation of the 3-deoxy group of Kdo with a unique $\mathrm{Fe}^{2+} / \alpha$-ketoglutarate $/ \mathrm{O}_{2}$-dependent Kdo-3- 
hydroxylase (KdoO) [48]. $\mathrm{KdoO}$ is an inner core assembly enzyme that functions after the Kdo-transferase KdtA but before the heptosyl-transferase WaaC enzyme during the Ko-containing LPS biosynthesis [49].

Gene homologues of transferase EptB (YhjW) transferring PEtN from phosphatidylethanolamine to Kdo [51] have also been found in the Y. pestis genome [35].

The structures of core oligosaccharide and lipid A among Y. pestis and Y. pseudotuberculosis strains are relatively conserved with no strain-to-strain variability in sugar composition. This observation is consistent with the discovery that the genes in the loci for core and lipid A biosynthesis are well conserved among Y. pestis and Y. pseudotuberculosis strains whose genomes have been sequenced, apart from the absence of the DD-Hep residue as a terminal sugar in the core of $Y$. pestis ssp. microti bvv. caucasica, hissarica, xilingolensis, talassica and altaica (Figure 2). Analysis of the $w a b C$ nucleotide sequence reveals differences among the $Y$. pestis isolates that result in amino acid variation in the polypeptide chain. The following two variable sites in the gene can be identified: (1) insertion of a guanosine at a position of 544 leading to the formation of a terminating codon, which results in the shortening of the polypeptide chain from 326 to 192 a.o. (bv. caucasica); (2) deletion of 14 nucleotides at a position of 84 also leading to the formation of a terminating codon, which results in the shortening of the polypeptide chain from 326 to 35 a.o. (bvv. altaica, xilingolensis, qinghaiensis, hissarica and talassica).

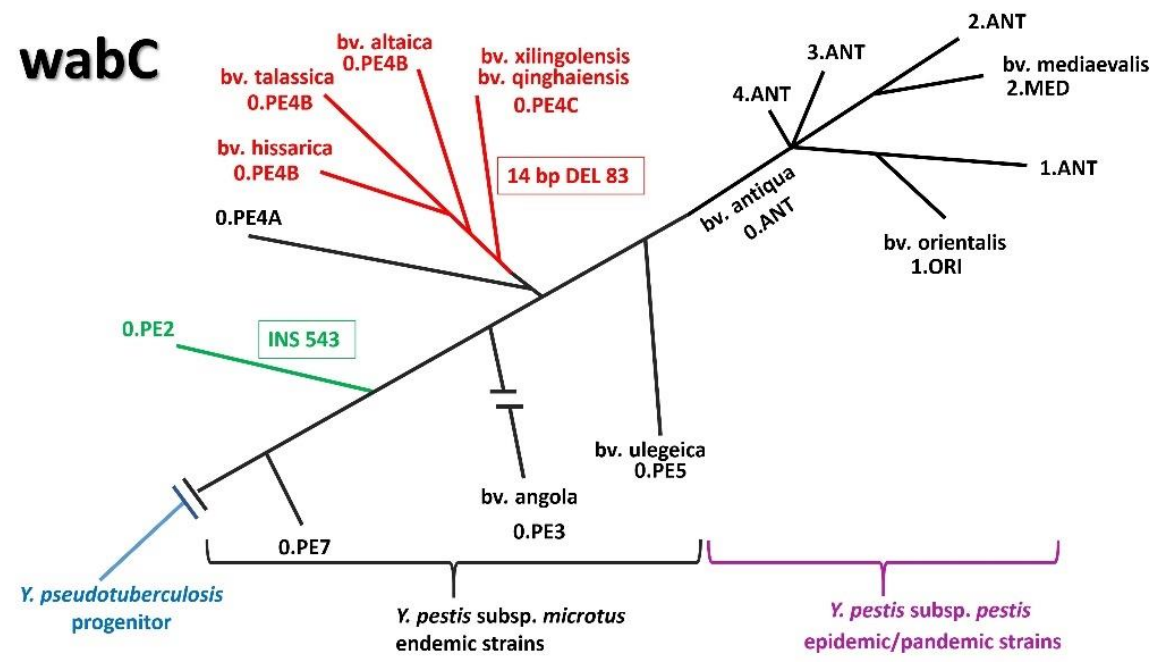

Figure 2. Schematic genomic tree and divergence based on core SNP analysis of 61 Y. pestis Genome Assembly and Annotation reports (https:/ /www.ncbi.nlm.nih.gov/genome/browse/\#! /prokaryotes/153/, accessed on 23 September 2021). The relationship among subspecies, biovars and SNP types is shown by Kislichkina [52].

The genetics and evolution of $Y$. pseudotuberculosis complex O-specific polysaccharides have been reviewed in great detail by Kenyon et al. [4]. All the Y. pseudotuberculosis complex OPS gene clusters are located between conserved genes hem $H$ and gsk. The gene cluster generally encodes the enzymes for NDP-sugar synthesis, the glycosyltransferases and polymerases needed for the assembly of the O-antigen. Genes specific to many of the $Y$. pseudotuberculosis O-antigen serotypes were identified in other species in the $Y$. pseudotuberculosis complex $[2,53]$. The serotyping of $Y$. pseudotuberculosis was originally developed using immunochemical assays [54] but has now been supplemented with genetic methods, such as PCR and sequencing [55]. The O-antigen serotyping scheme should apply to all the members of this complex [2].

Y. pestis isolates possess 17 genes similar to those in the $Y$. pseudotuberculosis O:1b OPS gene cluster, and five of them are inactivated by insertions or deletions, suggesting that the plague pathogen originated from its ancestor Y. pseudotuberculosis O:1b [56], having lost the ability to form $O$ polysaccharide during speciation $[6,55,57]$. Furthermore, 16 out of 17 genes of the two bacteria in O-antigen biosynthesis clusters are $99-100 \%$ identical, 
while the $w z x$ gene encoding flippase is only $90.4 \%$ identical [4]. It is assumed that, in contrast to Y. pseudotuberculosis WzX, which guarantees the transmembrane transfer of the UndPP-bound pentasaccharide repeating unit of the O-antigen, the flippase of $Y$. pestis is redirected to the transfer of one UndPP-bound GlcNAc residue across the inner membrane, which subsequently binds with the LPS core using WaaL ligase in the same position as the O polysaccharide in Y. pseudotuberculosis.

\section{Biological Effects of Y. pestis and Y. pseudotuberculosis Lipopolysaccharide}

LPS is an integral component of the outer membrane that is in direct contact with the host organism, taking part in the protection of bacterial cells against complement system components and other host defense mechanisms and systems [58,59]. Indeed, identification with the help of the whole-genome signature-tagged mutagenesis of the genes responsible for Y. pseudotuberculosis YPIII growth in the mammalian host organism showed that up to a third of the derivatives attenuated in the murine-pseudotuberculosis-infection model carried mutations in the LPS-biosynthesis (mainly LPS core or O-antigen biosynthesis) genes [60,61].

In a more recent study from another lab, the profile of the identified by dint of signature-tagged mutagenesis $Y$. pestis virulence-associated genes did not contain genes involved in LPS biosynthesis at all. The authors of the publication admit [62] that this may have been due to the fact that O-antigen-biosynthesis genes are non-functional in Y. pestis [57] and/or to the minor role of LPS in Y. pestis pathogenicity. The other reasons for inconsistency might be the use of different animal models and/or different routes of infection or just the limited representation of the library used for screening [62].

The detailed structure of lipopolysaccharide differs not only from one bacterial species to another but even within single species from one bacterial cell to another, which is consistent with the recent discovery of additional enzymes and gene products that can alter the basic structure of LPS adapting bacteria to exist in different environmental conditions, which in the case of pathogenic bacteria are various host niches. These modifications are not required for survival, but they are tightly regulated in the cell and are closely related to bacterial virulence [63].

Taking into account the complexity of the genetics of LPSs synthesis, the large number of enzymes and proteins responsible for the biosynthesis and export of LPSs, the dependence of the LPS structure on the cultivation conditions, as well as the simultaneous presence of several structural variants of LPS in the bacterial cell, one can expect significantly conflicting results in experiments not only carried out in different laboratories, but even in the same laboratory. To avoid this problem, it would be reasonable to assess the contribution of individual structural components of yersiniae LPSs to the pathogenesis of plague infection using standard operating procedures on sets of isogenic mutants generated on the basis of similar if not the same well-characterized "wild-type" strains. To reduce the multicomponent nature of such experiments, it is better to compare only one function of this polyfunctional molecule in one study.

\subsection{LPS Recognition by Innate Immunity}

The LPS of Gram-negative bacteria plays multiple key roles in the interaction between the pathogen and the infected host. First, LPS is among the pathogen-associated molecular patterns (PAMPs) recognized by Toll-like receptors (TLR), the structure and properties of which depend both on the species of the bacterium and on the conditions of its cultivation [64]. The evasion of innate immunity through the decrease in the detectability of pathogen-associated patterns to their complete invisibility underlies the pathogenesis of the plague. During its cyclic alternate existence in organisms of mammalian hosts and insect vectors, Y. pestis modifies its outer leaflet of the outer membrane by changing the structure of the lipid A portion of its LPS recognized by TLR4-MD2. Depending on the structure of LPS lipid A, Y. pestis, as with any other bacterium, is either recognized by the host organism as a foreign molecular structure of infectious origin that then triggers a cascade of immune 
responses of optimal strength aimed at eliminating the pathogen (immunostimulatory hexa-acyl LPS), or it evades detection by the immune system (immune-evasive tetra-acyl and penta-acyl LPS), leading to the uncontrolled multiplication of the plague pathogen (septicemia), accompanied by the massive production of LPS with low endotoxic activity, which, when the "critical mass" is reached (endotoxemia), in any case, causes the excessive uncontrolled production of proinflammatory cytokines, including the major mediator of septic shock, tumor necrosis factor $\alpha$ (TNF- $\alpha$ ), and ultimately leads to septic shock development $[28,32,65,66]$. Y. pestis LPS stimulated the production of TNF- $\alpha$ and IL-6 from mouse macrophages but was less active in these assays than the LPS isolated from E. coli strain 0111 [67].

An agonistic activity of LPS from wild-type $Y$. pestis in relation to TLR4 was compared with that of LPSs from E. coli mutants deficient in LpxM and LpxP acyltransferases, which were in charge of the embedding of secondary fatty acid residues (12:0 and 16:1) into lipid A, as well as to LPSs from bacteria of the genus Psychrobacter comprising lipid A fatty acids with shorter acyl chains (C10-C12) than those in lipid A from Y. pestis or E. coli (C12-C16). A dependence of the TNF- $\alpha$-inducing activity of LPS on the number or length of acyl chains within lipid A was revealed [68].

\subsection{LPS Interaction with Antimicrobial Peptides (AMPs)—The First Line of Defense in Innate Immunity}

Cationic antimicrobial peptides (CAMPs), which are among the classes of AMPs (such as defensins, cathelicidins and kinocidins), the most ancient and efficient components of host defense, play a central role as effector molecules of innate immunity. The majority of them not only hastily kill a wide range of bacteria but also modulate immunity and other host responses [69].

CAMP resistance in the plague pathogen as well as in a number of other Gramnegative bacteria depends on LPS modifications with Ara4N [70] that are believed to camouflage both of the two Y. pestis LPS domains, namely, lipid A and core polysaccharide negative charges, and decrease the affinity of positively charged CAMP to the bacterial superficies. A high resistance of the wild-type $Y$. pestis strains with a near-stoichiometric content of Ara4N in the LPS (two Ara4N residues per molecule), which is attained by culturing bacteria at $20-28{ }^{\circ} \mathrm{C}$, has been demonstrated using the polymyxin B model. A decrease in the resistance to CAMP correlates with a noticeable drop in the content of Ara $4 \mathrm{~N}$ as the temperature is increased up to $37^{\circ} \mathrm{C}[66,71]$. Mutants with gene gall knockouts encoding the pathway of Ara4N synthesis [72], arnT [35,45,46] encoding Ara4Ntransferase or phoP $[30,32]$ modulating the binding of Ara $4 \mathrm{~N}$ to lipid A are sensitive to CAMP independently of the cultivation temperature. The role of Ara4N is also supported by a marked increase in the content of this monosaccharide in the LPS of bacteria cultivated at $37^{\circ} \mathrm{C}$ in the presence of polymyxin B [28]. An increase in the Ara $4 \mathrm{~N}$ content in LPS and, as a result, in the resistance of $Y$. pestis to CAMPs with a decreasing cultivation temperature is undoubtedly of adaptive character. High resistance to polymyxin B at a temperature characteristic of insects can presumably be attributed to a greater contribution of CAMPs to the innate immunity defense mechanisms of insects as compared to that of mammals, which have a complement system in addition to CAMPs. More recently, the crucial role of Ara4N modification in $Y$. pestis LPS in guaranteeing resistance against Xenopsylla cheopis cheopin, flea cecropin CAMP, was experimentally proven [73].

Another cationic component of LPS, glycine [28], located in the core, can contribute to a certain extent to the resistance to CAMPs, whereas uncharged core components do not seem to play a significant role. An increase in the susceptibility to polymyxin B, which was observed for a set of knockout mutants at glycosyltransferase genes producing a truncated core could presumably be attributed to the simultaneous decrease in the Ara4N content in lipid A due to the inefficiency of the Ara4N transfer to LPS molecules with an incomplete carbohydrate moiety $[29,35,45]$.

The core oligosaccharides of $Y$. pestis could be modified at very low temperatures $\left(6^{\circ} \mathrm{C}\right)$ by phosphoethanolamine (PEtN) $[29,74]$. Analogous to Ara4N, the incorporation of PEtN 
decreases the negative charge on the LPS [75]. It was supposed that PEtN decoration may be accountable for $Y$. pestis resistance to the CAMPs produced by the wintering flea [74].

At $25-28{ }^{\circ} \mathrm{C}$, lipid A containing $3-6$ acyl groups is synthesized, while at $37^{\circ} \mathrm{C}$, it is mostly tetraacylated $[28,64]$. While the tetraacylated form may help to overcome warmblooded-host immunity, it makes Y. pestis more susceptible to the AMP cecropin A [37]. Resistance to AMP, dependent on the structure of lipid A, is not uncommon in other bacterial species as well $[39,42]$. Y. pestis AMP resistance is not only dependent on LPS structural changes, since mutants with an intact LPS structure, but susceptible to AMPs and reduced survival rates in fleas are described [73]. The majority of researchers studying Y. pestis AMP resistance have applied PB as a model peptide [28,32,35,46,47,72,76-85]; however, some $Y$. pestis PB-resistant mutants were not fully resistant to protamine or LL-37, and vice versa, which indicates that resistance to structurally unrelated types of peptides may be dissimilar $[79,86]$.

Antimicrobial chemokines (AMCs) are a recently identified family of peptides defending different organisms from bacterial infection [50]. Y. pseudotuberculosis mutants with improved binding to the AMCs CCL28 and CCL25 also had an increased susceptibility to chemokine-dependent cell death. The vast majority of mutants with enhanced binding to AMCs were defective in genes related to LPS biosynthesis. An especially significant influence on susceptibility to AMC-mediated killing was observed in the case of disruption of the hldD/waaF/waaC operon, necessary for ADP-L-glycero-D-manno-heptose synthesis and a complete LPS core oligosaccharide. The periodate oxidation of surface carbohydrates also enhanced AMC binding, while the enzymatic elimination of surface proteins pointedly decreased binding. Altogether, this suggests that the structure of $Y$. pseudotuberculosis LPS significantly affects the antimicrobial potency of AMCs preventing them from interaction with the bacterial cell surface proteins.

\subsection{Lipopolysaccharide and Yersiniae Virulence}

A Y. pseudotuberculosis O-polysaccharide-deficient derivative had reduced virulence upon the subcutaneous challenge of mice. The inability to produce LPS with O-side polysaccharide chains alone turned out to be insufficient for the emergence of a hypervirulent phenotype that distinguishes $Y$. pestis from its progenitor, Y. pseudotuberculosis [87]. Highdensity array-based signature-tagged mutagenesis was used to search for novel yersiniae virulence-associated genes. In about a third of attenuated mutants, the transposon was inserted into the genes responsible for the synthesis of the O-antigen or core [60].

The ability to synthesize a stealthy, hypoacylated lipid A structure, which is absent in other Yersiniaceae, arose in Y. pestis as a result of the absence of the lpxL gene and a mutation in the pagP gene, which encode two of the lipid A late acyltransferases [88]. It was shown that $Y$. pestis LPS from bacteria grown at $37^{\circ} \mathrm{C}$ can inhibit the stimulation of human monocyte-derived dendritic cells not only via TLR4 signaling but also via TLR2 and TLR3 [89].

Temperature determines the structure of LPS in Y. enterocolitica and Y. pseudotuberculosis; bacteria grown at $22-25{ }^{\circ} \mathrm{C}$ produce large amounts of $\mathrm{O}$-antigen, while bacteria grown at $37^{\circ} \mathrm{C}$ produce only its trace amounts [90]. The loss by $Y$. pestis of the ability to produce LPS with long O-side polysaccharide chains in the course of the evolution turned out to be beneficial for the new lifestyle of $Y$. pestis in a new ecological niche, removing the obstacle that prevented the direct contact of pathogenic factors located on the surface of the bacterial cells with their molecular targets in both the warm-blooded host and flea vector [57].

Thus, the complement-dependent killing of bacteria is among the first lines of defense of mammalian innate immunity against pathogens. The temperature dependence of the manifestation of serum resistance in Y. pseudotuberculosis [91] is associated with the synthesis of O-side chains of LPS. The absence of long O-polysaccharides in Y. pseudotuberculosis LPS at $37^{\circ} \mathrm{C}$, and in $Y$. pestis also at $20-28^{\circ} \mathrm{C}$, does not prevent the direct contact of AilC with complement resulting in serum resistance [92]. 
In some Gram-negative enteropathogens, the full-size O-antigen exerts an antiphagocytic role, preventing the uptake of bacteria. Lipooligosaccharide devoid of O-side chains does not protect bacterial cells from being swallowed by host phagocytes. Lipooligosaccharide, which is constitutively produced by $Y$. pestis at any temperature [93] and in Y. pseudotuberculosis at $37^{\circ} \mathrm{C}$ [94], does not interfere with phagocytosis, but the latter remains incomplete. Viable bacteria within a eukaryotic cell are not recognized by the host's immune system and are carried through the bloodstream throughout the host's body.

The loss of O-antigen represents a critical step in the evolution of $Y$. pseudotuberculosis into Y. pestis in terms of hijacking APCs, promoting bacterial dissemination and causing the plague. Host cell takeover is guaranteed by the interaction of the core portion of LPS with a DC-specific intercellular adhesion molecule-grabbing non-integrin (DC-SIGN SIGN) (CD209) receptor, expressed by APCs. Y. pestis engineered to produce LPS with O-side chains lost its ability to penetrate into the APCs [95]. More recently, it was shown that Y. pestis utilizes its core LPS to interact with mouse DC-SIGN-related protein 1 (SIGNR1, CD209b), a C-type lectin receptor expressing on the splenic marginal zone, lymph nodes, peritoneal macrophages and playing a role in lymphocyte migration from the blood into tissues, leading to bacterial dissemination to the lymph nodes, spleen and liver, and the initiation of a systemic infection. It was proposed that the loss of $\mathrm{O}$-antigen represents a critical step in the evolution of Y. pseudotuberculosis into Y. pestis in terms of hijacking APCs, promoting bacterial dissemination and causing the plague [93]. A highly specific protein-LPS association was found for the R-LPS and the porin proteins of E. coli, Y. pseudotuberculosis, Y. enterocolitica and S. minnesota co-extracted from these strains as a high molecular weight protein-LPS complex using the phenol-chloroform-petroleum ether method [96,97]. Among bacterial pathogens, representatives of the OmpA family of porin proteins play important roles in adhesion, invasion or intracellular survival as well as the evasion of host defenses or stimulators of pro-inflammatory cytokine production [98]. Unlike in other bacterial pathogens in which OmpA can promote adherence, invasion or serum resistance, the OmpA of $Y$. pestis and $Y$. pseudotuberculosis is restricted to enhancing intracellular survival [99], and we can speculate that this property is LPS dependent.

Y. pestis surface protease Pla is among the key pathogenicity factors of the bacterium. The manifestation of the multifunctional activities of Pla requires its binding to LPS. In this case, the spatial proximity of the oligosaccharide of the LPS core of the plague pathogen and the outer loops of the Pla protein molecule makes it possible for LPS to influence Pla conformation. The binding of the core part of LPS to Pla occurs at the amino acid residues $\operatorname{Arg}_{138}$ and $\operatorname{Arg}_{171}$, which induces conformational changes in the active site, affects its stereometry and modulates the activity of $Y$. pestis plasminogen activator. The substitution of these arginine residues, particularly $\mathrm{Arg}_{138}$, reduces the proteolytic activity of Pla and the quantity of Pla in bacteria [92,100-102]. The removal of LPS (lipo-chaperone) results in Pla deactivation. The high enzymatic activity of Pla in bacteria without steric interferences generated by the O-polysaccharide side chains is one of the main pathogenetic rewards of the R-form LPS in Y. pestis. On the other hand, an alternative suggestion was made that the need for LPS for the manifestation of the activity by the Pla protease ensures the absence of enzymatic activity of the plasminogen activator in the bacterial cytoplasm and its functioning only when incorporated into the outer membrane.

The introduction of $Y$. pestis plasmid pPla that carries the pla gene into both the Y. pseudotuberculosis strain expressing smooth LPS and its mutant, which, as a wild-type Y. pestis, was able to produce only O-antigen-deficient LPS, caused Pla synthesis, export to the outer membrane and processing as in Y. pestis. The ability of Pla to activate plasminogen was observed only in the strains producing O-antigen-free lipooligosaccharide [87].

The outer membrane protein $\mathrm{X}(\mathrm{OmpX})$ / Ail (adhesion invasion locus) in Y. pestis is required for efficient bacterial adherence to and internalization by cultured HEp-2 cells and confers resistance to human and rat serum. The deletion of ail in the CO92 strain delayed the time to death by up to $48 \mathrm{~h}$ in a mouse model and completely attenuated the virulence of the ail-deficient derivate in a rat model of the disease [103]. 
Working as a single whole, Ail and LPS, through a mutual action, create an optimal Ail conformation on the surface of the bacterial membrane and cause thickening and stiffness of the LPS membrane, which together contribute to the survival of Y. pestis in human serum, antibiotic resistance and the integrity of the cell envelope [104].

The Ail from Y. pestis and Y. pseudotuberculosis is identical, except for one or two amino acids at positions 43 and 126, depending on the $Y$. pseudotuberculosis strain. It was reported that Ail from the Y. pseudotuberculosis strain YPIII was not able to bind to host cells. It was found that Ail from both the Yersinia species can provide adhesion and invasion, but the long O-side polysaccharide chains of $Y$. pseudotuberculosis LPS prevent the contact of Ail with the host cells [105].

The genetic-engineering modification of the structure of Y. pestis LPS has shown the importance of individual components of this biomolecule for bacterial virulence. An isogenic set of knockout mutants [35] based on the full-virulent strain 231 [52], differing in the degree of core truncation, showed that $Y$. pestis knock-out mutants with two or less sugar residues in the LPS core were highly susceptible to antimicrobial cationic peptides and human serum as well as avirulent in murine and guinea pig subcutaneous infection models (Figure 3).

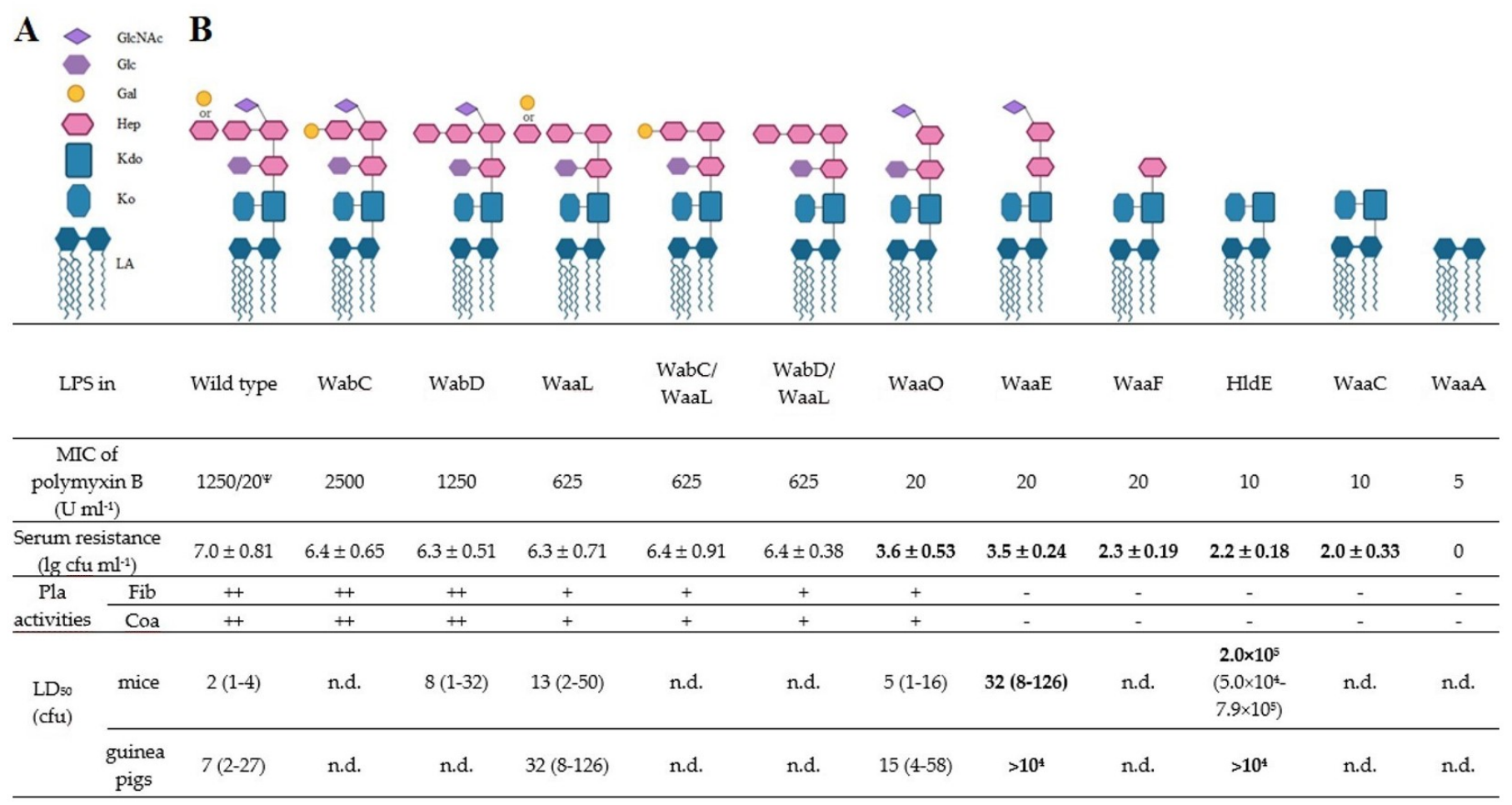

Figure 3. Biological properties of wild-type Y. pestis strain 231 and derived LPS mutants. (A) Key to LPS moieties. (B) LPS core structures of Y. pestis 231 and its isogenic mutants. Data are a summary of previous work on LPS of Y. pestis 231 [35] LA and wild-type lipid A; when both are present, DD-HepIV and Gal alternate at the non-reducing end. In all strains, terminal Ko is partially replaced with terminal Kdo. Significant changes in biological properties are indicated in bold face. MIC, minimal inhibitory concentration; cfu, colony forming unit; $/ 20^{\Psi}$, MIC at $6{ }^{\circ} \mathrm{C}$; n.d., not determined; Fib, fibrinolytic activity; a positive fibrinolysis test "++" was represented by complete clot lysis; a positive test "+" was represented by any degree of lysis; a negative test " -" was represented by a solid clot; CoA, coagulase activity; a positive coagulase test "++" was represented by a solid clot; a positive test " + " was represented by any degree of incomplete clotting (from a loose clot to a solid clot in liquid plasma); a negative test "-" was represented by the absence of clotting.

In summary, for the normal functioning of LPS-dependent pathogenicity factors, Pla (bacteria intrahost dissemination), Ail (serum resistance) and antimicrobial cationic peptide resistance, the $Y$. pestis version of this complex macromolecule should include in 
its core structure at least five to seven sugar residues [35]. All eight wild-type Y. pestis core constituent sugars are necessary for the maximal enzymatic activities of Pla.

\section{Immunogenicity and Protective Efficacy of Yersinia Lipopolysaccharide}

Immunization with Y. pestis LPS alone as well as together with cholera toxin B subunit [67], Shigella dysenteriae outer membrane proteins [106] or in a complex with Y. pestis outer membrane proteins [107] in all cases resulted in the development of an antibody response to LPS but failed to protect mice against a challenge of virulent $Y$. pestis. Moreover, Y. pestis LPS, when injected simultaneously with F1 capsular antigen, produced an immunosuppressive effect in revaccinated Papio hamadryas [108].

Although it is not a protective antigen, Y. pestis LPS is, nevertheless, of interest for the design of vaccine preparations, since it allows the regulation of the immune response to the introduction of other antigens. Thus, the emergence in the virulent strains of the ability to include the sixth fatty acid residue into its LPS at $37^{\circ} \mathrm{C}$ leads to the recognition of the pathogen and prevents its reproduction and, accordingly, avoids the host's death, but contributes to the formation of intense protective immunity [109]. On the other hand, the inability of a vaccine strain to synthesize endotoxic six-acyl LPS at $28^{\circ} \mathrm{C}$ allows the attenuated strain to multiply unhindered and induce approximately the same potent immune response [110].

Priming the innate immune system using the aminoalkyl glucosaminide 4-phosphate (AGP) Toll-like receptor 4 (TLR4) ligands of Toll-like receptor 4 (TLR4), synthetic lipid A mimetics, prolonged the time to death or even protected mice from lethal intranasal challenge with Y. pestis CO92. AGP protection was TLR4 dependent and was not observed in TLR4-deficient transgenic mice. AGP therapy, in combination with sub-therapeutic doses of gentamicin, significantly increased survival. It has been suggested that, in combination with other treatments, AGPs could be used to protect immunologically naïve people from the plague [111].

\section{Phages Target LPS}

The exposure of a significant part of the LPS molecule in the extracellular environment makes these parts the main receptors for bacteriophages. The LPS-specific phages of Y. pseudotuberculosis/Y. pestis are shown in Table 5. Not all the phages of Y. pestis use LPS as their only receptor; for example, the receptor of the YpP-R phage extends beyond the LPS core [112], and the outer membrane proteins of Y. pestis, Ail and OmpF, participate together with the LPS core in Yep-phi adsorption [113]. ҮpfФ can use several different cell surface molecules as receptors [114].

Table 5. Components of the Y. pestis LPS as a specific receptor for bacteriophages.

\begin{tabular}{cccc}
\hline Group & Bacteriophage & Receptor & References \\
\hline & PhiA1122 & Kdo/Ko of LPS & {$[115-118]$} \\
\cline { 2 - 4 } & YpP-Y & Hep(I)/Glc of LPS & {$[112,119,120]$} \\
\cline { 2 - 4 } T7 & YpP-R & Beyond the LPS core & {$[119,120]$} \\
\cline { 2 - 4 } & Yep-phi & LPS; OmpF; Ail & {$[113,121]$} \\
\cline { 2 - 4 } & Pokrovskaya & Hep(II)/Hep(III) of LPS & {$[120-122]$} \\
\cline { 2 - 4 } & T7Yp & Hep(I)/Glc of LPS & {$[112]$} \\
\hline \multirow{2}{*}{ P2 } & P-413C & GlcNAc of LPS & {$[112,119,120]$} \\
\hline \multirow{2}{*}{ T4 } & PhijA1 & Kdo/Ko of LPS & {$[112,119,120]$} \\
\hline & YpsP-PST & Hep(II)/Hep(III) of LPS & {$[112,119,120,123]$} \\
\hline
\end{tabular}


Periodically, papers are published on the isolation of new Y. pestis-specific phages and the study of the spectrum of their host specificity, the possibility of using them for decontamination and therapy. Unfortunately, researchers do not always reach the point of determining the receptors for these bacteriophages [124,125].

\section{Conclusions}

Y. pseudotuberculosis is a serologically heterogeneous species, including strains with structurally diverse OPSs, which define the classification of these bacteria into 18 O-serotypes. A peculiar feature of many OPSs is the presence of various of 3,6-dideoxyhexoses, Y. pseudotuberculosis being the only bacterial species that produces all known natural isomers of these monosaccharides. OPSs of several O-serotypes contain a unique eight-carbon branched monosaccharide, called yersiniose A (Yer), which has been found in Y. pseudotuberculosis for the first time ever. Although diverse, the OPSs can be grouped based on the identical main chain structure or the same terminal side-chain monosaccharide.

In contrast, $Y$. pestis lacks any OPS owing to mutations in 5 of the 17 genes of the O-antigen biosynthesis gene cluster inherited from Y. pseudotuberculosis. In the LPS of $Y$. pestis and the R-form LPS of Y. pseudotuberculosis, the OPS chain is replaced with a single $\beta$-D-GlcNAc residue.

There are significant similarities of the core and lipid A structures of $Y$. pseudotuberculosis and Y. pestis. A major difference of Y. pseudotuberculosis is the presence of lipid A species that contain a secondary 16:0 acyl group, which are not present in $Y$. pestis due to a mutation in the corresponding acyltransferase gene (pagP) [36]. A significant distinction of $Y$. pestis bvv. caucasica and altaica is a shorter core as compared to the main subspecies, $Y$. pestis ssp. pestis, due to the inability of the non-main subspecies to incorporate DD-Hep into the LPS.

The LPS structures of both Y. pseudotuberculosis and Y. pestis undergo essentially the same temperature-dependent variations that contribute to the intrinsic heterogeneity of the LPS and change the charge of the cell surface $[5,7,8]$. Thus, the elevation of the growth temperature causes a decrease in the positive charge by diminishing the content of Ara4N and an increase in the negative charge by additional phosphorylation in lipid A to produce a diphosphate group.

Several variations, such as the replacement of DD-Hep with Gal in the core and the glycosylation of the phosphate groups of lipid A with Ara4N, are regulated by the twocomponent signal transduction PhoPQ system [30,32], but this system is not involved in the 3-hydroxylation of Kdo and control of lipid A acylation.

Temperature-dependent LPS structure variations are biologically significant and can be considered as part of a unique mechanism elaborated by $Y$. pseudotuberculosis for adaptation to different conditions in the soil and mammalian host and adopted by $Y$. pestis for the flea-borne type of transmission [5]. Indeed, the incorporation of Ara4N into lipid A, which enhances the resistance of $Y$. pestis to cationic antimicrobial peptides by a decrease in their affinity for the LPS, may promote the growth of $Y$. pestis in fleas, which elaborate antimicrobial peptides as a significant component of their innate immune system. An adaptive response to conditions in the mammalian host includes a decrease in the number of acyl groups in lipid A at $37^{\circ} \mathrm{C}$, which reduces the recognizability of the LPS $[32,66]$ by innate immunity and, as a result, compromises the host's immune response to infection.

The exact biological role of the core structure variations remains unknown, but it has been speculated that the 3-hydroxylation of Kdo and incorporation of Gal and PEtN to the core at lower temperatures are among the LPS modifications that are beneficial for the asymptomatic persistence of the bacterium in the mammalian host during winter hibernation and in active insects [2,4].

A number of in vitro and in vivo investigations have shown the crucial role of phospholipids and LPSs in the folding and topogenesis of membrane proteins [126-130], as the basis for classifying these lipid-containing molecules as lipo-chaperones. 
Summarizing the abovementioned findings, we can state that LPS is not only an endotoxin and a thermostable component of the outer leaflet of the outer membrane of Gram-negative microorganisms, which ensures the structural integrity of the bacterial cell and protects the membrane from aggressive environmental influences, acts as bacteriophage receptor and TLR4 ligand, but is also a kapellmeister, making sure that its orchestra members, protein factors of pathogenicity, played harmoniously and entered on time.

It is obvious that structural studies of LPS, along with studies of the genetic coding of its biosynthesis, are far ahead of studies on the biological significance of this biomolecule, which are in their infancy. It is necessary to make significant efforts to identify the real contribution of various structural elements of different structural variants of this multifunctional molecule, which are actually synthetized within the flea vector or mammalian host, to the molecular mechanisms of pathogenesis and immunogenesis of various clinical forms of plague in various laboratory animals.

There is still a large amount to understand and study, and "microbe hunters" will stay relevant for a long time.

Author Contributions: Conceptualization, Y.A.K. and S.V.D.; writing—original draft preparation, Y.A.K., A.A.K., A.P.A. and S.V.D.; writing-review and editing, Y.A.K., A.A.K., A.P.A., A.N.K., O.V.B., A.S.V., K.Y.S., A.S.S. and. S.V.D.; visualization, Y.A.K. and S.V.D. All authors have read and agreed to the published version of the manuscript.

Funding: In the publication of this article, S.V.D., A.P.A., A.S.V. and A.A.K. were supported by the Ministry of Science and Higher Education of the Russian Federation (agreement number 075-15-2019-1671).

Conflicts of Interest: The authors declare no conflict of interest.

$\begin{array}{ll}\text { Abbreviations } & \\ \text { 6dAlt } & \text { 6-deoxyaltrose } \\ \text { 6dmanHep } & \text { 6-deoxy-D-manno-heptose } \\ \text { Abe } & \text { 3,6-dideoxy-D-xylo-hexose (abequose) } \\ \text { Asc } & \text { 3,6-dideoxy-L-arabino-hexose (ascarylose) } \\ \text { Col } & \text { 3,6-dideoxy-L-xylo-hexose (colitose) } \\ \text { FucNAm } & \text { 2-acetimidoylamino-2-deoxyfucose } \\ \text { GlcNAcA } & \text { 2-acetamido-2-deoxyglucuronic acid } \\ \text { Par } & \text { 3,6-dideoxy-D-ribo-hexose (paratose) } \\ \text { Qui } & \text { 6-deoxyglucose (quinovose) } \\ \text { Tyv } & \text { 3,6-dideoxy-D-arabino-hexose (tyvelose) } \\ \text { Yer } & \text { 4-C-[(S)-1-hydroxyethyl]-3,6-dideoxy-D-xylo-hexose (yersiniose A) } \\ \text { GlcNAc } & \text { 2-acetamido-2-deoxyglucose } \\ \text { GalNAc } & \text { 2-acetamido-2-deoxygalactose } \\ \text { EtNP } & \text { 2-aminoethyl phosphate } \\ \text { L- } \alpha \text {-D-Hep } & \text { L-glycero- } \alpha \text {-D-manno-heptose } \\ \text { D- } \alpha \text {-D-Hep } & \text { D-glycero- } \alpha \text {-D-manno-heptose } \\ \text { Gal } & \text { galactose } \\ \text { Glc } & \text { glucose } \\ \text { Kdo } & \text { 3-deoxy-D-manno-oct-2-ulosonic acid } \\ \text { Ko } & \text { D-glycero-D-talo-oct-2-ulosonic acid } \\ \text { Ara4N } & \text { 4-amino-4-deoxy-L-arabinose } \\ \text { GlcN } & \text { glucosamine } \\ \text { PEtN } & \text { phosphoethanolamine } \\ \text { UndP,UndPP } & \text { undecaprenyl phosphate/diphosphate } \\ \text { CAMP } & \text { cationic antimicrobial peptides } \\ \text { LPS } & \text { lipopolysaccharide } \\ \text { R-formLPS } & \text { rough LPS } \\ \text { S-formLPS } & \text { smooth form LPS } \\ \text { NHS } & \text { normal human serum } \\ \text { AMPs } & \text { antimicrobial peptides } \\ & \\ & \end{array}$




$\begin{array}{ll}\text { AMCs } & \text { antimicrobial chemokines } \\ \text { AGP } & \text { aminoalkyl glucosaminide 4-phosphate } \\ \text { TLR4 } & \text { Toll-like receptor } 4 \\ \text { PAMP } & \text { pathogen-associated molecular patterns } \\ \text { DC } & \text { dendritic cell }\end{array}$

\section{References}

1. Tsubokura, M.; Aleksic, S. A simplified antigenic scheme for serotyping of Yersinia pseudotuberculosis: Phenotypic characterization of reference strains and preparation of $\mathrm{O}$ and $\mathrm{H}$ factor sera. Contrib. Microbiol. Immunol. 1995, 13, 99-105.

2. Laukkanen-Ninios, R.; Didelot, X.; Jolley, K.A.; Morelli, G.; Sangal, V.; Kristo, P.; Brehony, C.; Imori, P.F.; Fukushima, H.; Siitonen, A.; et al. Population structure of the Yersinia pseudotuberculosis complex according to multilocus sequence typing. Environ. Microbiol. 2011, 13, 3114-3127. [CrossRef] [PubMed]

3. De Castro, C.; Kenyon, J.J.; Cunneen, M.M.; Molinaro, A.; Holst, O.; Skurnik, P.R. The O-specific polysaccharide structure and gene cluster of serotype O:12 of the Yersinia pseudotuberculosis complex, and the identification of a novel L-quinovose biosynthesis gene. Glycobiology 2012, 2, 346-353. [CrossRef] [PubMed]

4. Kenyon, J.J.; Cunneen, M.M.; Reeves, P.R. Genetics and evolution of Yersinia pseudotuberculosis O-specific polysaccharides: A novel pattern of O-antigen diversity. FEMS Microbiol. Rev. 2017, 41, 200-217. [CrossRef]

5. Knirel, Y.A.; Kondakova, A.N.; Bystrova, O.V.; Lindner, B.; Shaikhutdinova, R.Z.; Dentovskaya, S.V.; Anisimov, A.P. New features of Yersinia lipopolysaccharide structures as revealed by high-resolution electrospray ionization mass spectrometry. Adv. Sci. Lett. 2008, 1, 192-198. [CrossRef]

6. Skurnik, M.; Bengoechea, J.A. The biosynthesis and biological role of lipopolysaccharide O-antigens of pathogenic Yersiniae. Carbohydr. Res. 2003, 338, 2521-2529. [CrossRef]

7. Kondakova, A.N.; Ho, N.; Bystrova, O.V.; Shashkov, A.S.; Lindner, B.; Creuzenet, C.; Knirel, Y.A. Structural studies of the $\mathrm{O}$-antigens of Yersinia pseudotuberculosis O:2a and mutants thereof with impaired 6-deoxy-D-manno-heptose biosynthesis pathway. Carbohydr. Res. 2008, 343, 1383-1389. [CrossRef]

8. Wang, L.; Curd, H.; Qu, W.J.; Reeves, P.R. Sequencing of Escherichia coli O111 O-antigen gene cluster and identification of O111-specific genes. J. Clin. Microbiol. 1998, 36, 3182-3187. [CrossRef]

9. Kenne, L.; Lindberg, B. Bacterial polysaccharides. In The Polysaccharides; Aspinall, G.O., Ed.; Academic Press: New York, NY, USA, 1983; pp. 287-363.

10. Vinogradov, E.; Nossova, L.; Radziejewska-Lebrecht, J. The structure of the O-specific polysaccharide from Salmonella cerro (serogroup K, O:6,14,18). Carbohydr. Res. 2004, 339, 2441-2443. [CrossRef]

11. Kondakova, A.N.; Sevillano, A.M.; Shaikhutdinova, R.Z.; Lindner, B.; Komandrova, N.A.; Dentovskaya, S.V.; Shashkov, A.S.; Anisimov, A.P.; Skurnik, M.; Knirel, Y.A. Revision of the O-polysaccharide structure of Yersinia pseudotuberculosis O:1a; confirmation of the function of WbyM as paratosyltransferase. Carbohydr. Res. 2012, 350, 98-102. [CrossRef]

12. Kondakova, A.N.; Bystrova, O.V.; Shaikhutdinova, R.Z.; Ivanov, S.A.; Dentovskaya, S.V.; Shashkov, A.S.; Knirel, Y.A.; Anisimov, A.P. Structure of the O-antigen of Yersinia pseudotuberculosis O:4b. Carbohydr. Res. 2009, 344, 152-154. [CrossRef] [PubMed]

13. De Castro, C.; Kenyon, J.; Cunneen, M.M.; Reeves, P.R.; Molinaro, A.; Holst, O.; Skurnik, M. Genetic characterization and structural analysis of the O-specific polysaccharide of Yersinia pseudotuberculosis serotype O:1c. Innate Immun. 2011, 17, 183-190. [CrossRef] [PubMed]

14. Kondakova, A.N.; Bystrova, O.V.; Shaikhutdinova, R.Z.; Ivanov, S.A.; Dentovskaya, S.V.; Shashkov, A.S.; Knirel, Y.A.; Anisimov, A.P. Structure of the O-polysaccharide of Yersinia pseudotuberculosis O:2b. Carbohydr. Res. 2009, 344, 405-407. [CrossRef] [PubMed]

15. Kondakova, A.N.; Bystrova, O.V.; Shaikhutdinova, R.Z.; Ivanov, S.A.; Dentovskaya, S.V.; Shashkov, A.S.; Knirel, Y.A.; Anisimov, A.P. Reinvestigation of the O-antigens of Yersinia pseudotuberculosis: Revision of the O2c and confirmation of the O3 antigen structures. Carbohydr. Res. 2008, 343, 2486-2488. [CrossRef] [PubMed]

16. Kondakova, A.N.; Bystrova, O.V.; Shaikhutdinova, R.Z.; Ivanov, S.A.; Dentovskaya, S.V.; Shashkov, A.S.; Knirel, Y.A.; Anisimov, A.P. Structure of the O-antigen of Yersinia pseudotuberculosis O:4a revised. Carbohydr. Res. 2009, 344, 531-534. [CrossRef] [PubMed]

17. Kondakova, A.N.; Shaikhutdinova, R.Z.; Ivanov, S.A.; Dentovskaya, S.V.; Shashkov, A.S.; Anisimov, A.P.; Knirel, Y.A. Revision of the O-polysaccharide structure of Yersinia pseudotuberculosis O:1b. Carbohydr. Res. 2009, 344, 2421-2423. [CrossRef]

18. Cunneen, M.M.; De Castro, C.; Kenyon, J.; Parrilli, M.; Reeves, P.R.; Molinaro, A.; Holst, O.; Skurnik, M. The O-specific polysaccharide structure and biosynthetic gene cluster of Yersinia pseudotuberculosis serotype O:11. Carbohydr. Res. 2009, 344, 1533-1540. [CrossRef]

19. Gorshkova, R.P.; Korchagina, N.I.; Ovodov, Y.S. Structural studies on the O-specific side-chain polysaccharide of lipopolysaccharide from Yersinia pseudotuberculosis VA serovar. Eur. J. Biochem. 1983, 131, 345-347. [CrossRef]

20. Korchagina, N.I.; Gorshkova, R.P.; Ovodov, Y.S. Studies on O-specific polysaccharide from Yersinia pseudotuberculosis VB serovar. Bioorg. Khim. 1982, 8, 1666-1669. 
21. De Castro, C.; Skurnik, M.; Molinaro, A.; Holst, O. Characterization of the O-polysaccharide structure and biosynthetic gene cluster of Yersinia pseudotuberculosis serotype O:15. Innate Immun. 2009, 15, 351-359. [CrossRef]

22. Gorshkova, R.P.; Zubkov, V.A.; Isakov, V.V.; Ovodov, Y.S. Structural features of O-specific polysaccharide from lipopolysaccharide of Yersinia pseudotuberculosis VI serovar. Bioorg. Khim. 1983, 9, 1068-1073. [PubMed]

23. Zubkov, V.A.; Gorshkova, R.P.; Ovodov, Y.S.; Sviridov, A.F.; Shashkov, A.S. Synthesis of 3,6-dideoxy-4-C-(41-hydroxyethyl) hexopyranoses (yersinioses) from 1,6-anhydro- $\beta$-D-glycopyranose. Carbohydr. Res. 1992, 225, 189-207. [CrossRef]

24. Komandrova, N.A.; Gorshkova, R.P.; Zubkov, V.A.; Ovodov, Y.S. Structure of the O-specific polysaccharide chain of lipopolysaccharide of Yersinia pseudotuberculosis serovar VII. Bioorg. Khim. 1989, 15, 104-110.

25. Kenyon, J.J.; De Castro, C.; Cunneen, M.M.; Reeves, P.R.; Molinaro, A.; Holst, O.; Skurnik, M. The genetics and structure of the O-specific polysaccharide of Yersinia pseudotuberculosis serotype O:10 and its relationship to Escherichia coli O111 and Salmonella enterica O35. Glycobiology 2011, 21, 1131-11139. [CrossRef]

26. Beczala, A.; Ovchinnikova, O.G.; Duda, K.A.; Skurnik, M.; Radziejewska-Lebrecht, J.; Holst, O. Structure of Yersinia pseudotuberculosis O:9 O-specific polysaccharide repeating unit resolved. In Proceedings of the Abstracts of the 15th European Carbohydrate Symposium, Vienna, Austria, 19-24 July 2009; pp. 19-24.

27. Beczala, A.; Ovchinnikova, O.G.; Datta, N.; Mattinen, L.; Knapska, K.; Radziejewska-Lebrecht, J.; Holst, O.; Skurnik, M. Structure and genetic basis of Yersinia similis serotype O:9 O-specific polysaccharide. Innate Immun. 2015, 21, 3-16. [CrossRef]

28. Knirel, Y.A.; Lindner, B.; Vinogradov, E.V.; Kocharova, N.A.; Senchenkova, S.N.; Shaikhutdinova, R.Z.; Dentovskaya, S.V.; Fursova, N.K.; Bakhteeva, I.V.; Titareva, G.M.; et al. Temperature-dependent variations and intraspecies diversity of the structure of the lipopolysaccharide of Yersinia pestis. Biochemistry 2005, 44, 1731-1743. [CrossRef]

29. Knirel, Y.A.; Lindner, B.; Vinogradov, E.V.; Shaikhutdinova, R.Z.; Senchenkova, S.N.; Kocharova, N.A.; Holst, O.; Pier, G.B.; Anisimov, A.P. Cold temperature-induced modifications to the composition and structure of the lipopolysaccharide of Yersinia pestis. Carbohydr. Res. 2008, 343, 1625-1630. [CrossRef] [PubMed]

30. Hitchen, P.G.; Prior, J.L.; Oyston, P.C.; Panico, M.; Wren, B.W.; Titball, R.W.; Morris, H.R.; Dell, A. Structural characterization of lipo-oligosaccharide (LOS) from Yersinia pestis: Regulation of LOS structure by the PhoPQ system. Mol. Microbiol. 2002, 44, 1637-1650. [CrossRef]

31. Knirel, Y.A.; Dentovskaya, S.V.; Senchenkova, S.N.; Shaikhutdinova, R.Z.; Kocharova, N.A.; Anisimov, A.P. Structural features and structural variability of the lipopolysaccharide of Yersinia pestis, the cause of plague. J. Endotoxin Res. 2006, 12, 3-9. [PubMed]

32. Rebeil, R.; Ernst, R.K.; Gowen, B.B.; Miller, S.I.; Hinnebusch, B.J. Variation in lipid A structure in the pathogenic yersiniae. Mol. Microbiol. 2004, 52, 1363-1373. [CrossRef]

33. Therisod, H.; Karibian, D.; Perry, M.B.; Caroff, M. Structural analysis of Yersinia pseudotuberculosis ATCC 29833 lipid A. Int. J. Mass Spectrom. 2002, 219, 549-557. [CrossRef]

34. Raetz, C.R.; Whitfield, C. Lipopolysaccharide endotoxins. Annu Rev. Biochem. 2002, 71, 635-700. [CrossRef] [PubMed]

35. Dentovskaya, S.V.; Anisimov, A.P.; Kondakova, A.N.; Bystrova, O.V.; Lindner, B.; Svetoch, T.E.; Shaikhutdinova, R.Z.; Ivanov, S.A.; Bakhteeva, I.V.; Titareva, G.M.; et al. Functional characterization and biological significance of Yersinia pestis lipopolysaccharide biosynthesis genes. Biochemistry 2011, 76, 808-822. [CrossRef] [PubMed]

36. Bishop, R.E. The lipid A palmitoyltransferase PagP: Molecular mechanisms and role in bacterial pathogenesis. Mol. Microbiol. 2005, 57, 900-912. [CrossRef] [PubMed]

37. Rebeil, R.; Ernst, R.K.; Jarrett, C.O.; Adams, K.N.; Miller, S.I.; Hinnebusch, B.J. Characterization of late acyltransferase genes of Yersinia pestis and their role in temperature-dependent lipid A variation. J. Bacteriol. 2006, 188, 1381-1388. [CrossRef] [PubMed]

38. Dentovskaya, S.V.; Shaikhutdinova, R.Z.; Knirel, Y.A.; Ivanov, S.L.; Anisimov, A.P. Generation of Vaccine Strains of Gram-Negative Bacteria with Reduced Adverse Reactions. Mol. Gen. Mikrobiol. Virusol. 2006, 2, 3-8.

39. Gorzelak, P.; Klein, G.; Raina, S. Molecular Basis of Essentiality of Early Critical Steps in the Lipopolysaccharide Biogenesis in Escherichia coli K-12: Requirement of MsbA, Cardiolipin, LpxL, LpxM and GcvB. Int. J. Mol. Sci. 2021, 22, 5099. [CrossRef]

40. Reynolds, C.M.; Raetz, C.R. Replacement of lipopolysaccharide with free lipid A molecules in Escherichia coli mutants lacking all core sugars. Biochemistry 2009, 48, 9627-9640. [CrossRef]

41. Klein, G.; Lindner, B.; Brabetz, W.; Brade, H.; Raina, S. Escherichia coli K-12 Suppressor-free Mutants Lacking Early Glycosyltransferases and Late Acyltransferases: Minimal lipopolysaccharide structure and induction of envelope stress response. J. Biol. Chem. 2009, 284, 15369-15389. [CrossRef]

42. Guo, L.; Lim, K.B.; Poduje, C.M.; Daniel, M.; Gunn, J.S.; Hackett, M.; Miller, S.I. Lipid A acylation and bacterial resistance against vertebrate antimicrobial peptides. Cell 1998, 95, 189-198. [CrossRef]

43. Aussel, L.; Therisod, H.; Karibian, D.; Perry, M.B.; Bruneteau, M.; Caroff, M. Novel variation of lipid A structures in strains of different Yersinia species. FEBS Lett. 2000, 465, 87-92. [CrossRef]

44. Trent, M.S.; Ribeiro, A.A.; Lin, S.; Cotter, R.J.; Raetz, C.R. An inner membrane enzyme in Salmonella and Escherichia coli that transfers 4-amino-4-deoxy-L-arabinose to lipid A: Induction on polymyxin-resistant mutants and role of a novel lipid-linked donor. J. Biol. Chem. 2001, 276, 43122-43131. [CrossRef] [PubMed]

45. Anisimov, A.P.; Dentovskaya, S.V.; Kondakova, A.N.; Lindner, B.; Shaikhutdinova, R.Z.; Kocharova, N.A.; Senchenkova, S.N.; Knirel, Y.A. Yersinia pestis lipopolysaccharide in host-pathogen interactions. In The Challenge of Highly Pathogenic Microorganisms. Mechanisms of Virulence and Novel Medical Countermeasures; Shafferman, A., Ordentlich, A., Velan, B., Eds.; Springer: Dordrecht, The Netherlands; London, UK; New York, NY, USA, 2010; pp. 77-87. [CrossRef] 
46. Knirel, Y.A.; Dentovskaya, S.V.; Bystrova, O.V.; Kocharova, N.A.; Senchenkova, S.N.; Shaikhutdinova, R.Z.; Titareva, G.M.; Bakhteeva, I.V.; Lindner, B.; Pier, G.B.; et al. Relationship of the lipopolysaccharide structure of Yersinia pestis to resistance to antimicrobial factors. Adv. Exp. Med. Biol. 2007, 603, 88-96. [CrossRef] [PubMed]

47. Winfield, M.D.; Latifi, T.; Groisman, E.A. Transcriptional regulation of the 4-amino-4-deoxy-L-arabinose biosynthetic genes in Yersinia pestis. J. Biol. Chem. 2005, 280, 14765-14772. [CrossRef]

48. Chung, H.S.; Raetz, C.R. Dioxygenases in Burkholderia ambifaria and Yersinia pestis that hydroxylate the outer Kdo unit of lipopolysaccharide. Proc. Natl. Acad. Sci. USA 2011, 108, 510-515. [CrossRef] [PubMed]

49. Chung, H.S.; Yang, E.G.; Hwang, D.; Lee, J.E.; Guan, Z.; Raetz, C.R. Kdo hydroxylase is an inner core assembly enzyme in the Ko-containing lipopolysaccharide biosynthesis. Biochem. Biophys. Res. Commun. 2014, 452, 789-794. [CrossRef]

50. Erickson, D.L.; Lew, C.S.; Kartchner, B.; Porter, N.T.; McDaniel, S.W.; Jones, N.M.; Mason, S.; Wu, E.; Wilson, E. Lipopolysaccharide biosynthesis genes of Yersinia pseudotuberculosis promote resistance to antimicrobial chemokines. PLoS ONE 2016, 11, e0157092. [CrossRef]

51. Reynolds, C.M.; Kalb, S.R.; Cotter, R.J.; Raetz, C.R. A phosphoethanolamine transferase specific for the outer 3-deoxy-D-mannooctulosonic acid residue of Escherichia coli lipopolysaccharide. Identification of the eptB gene and Ca2+ hypersensitivity of an eptB deletion mutant. J. Biol. Chem. 2005, 280, 21202-21211. [CrossRef]

52. Kislichkina, A.A.; Platonov, M.E.; Vagaiskaya, A.S.; Bogun, A.G.; Dentovskaya, S.V.; Anisimov, A.P. Rational Taxonomy of Yersinia pestis. Mol. Genet. Microbiol. Virol. 2019, 34, 110-117. [CrossRef]

53. Savin, C.; Martin, L.; Bouchier, C.; Filali, S.; Chenau, J.; Zhou, Z.; Becher, F.; Fukushima, H.; Thomson, N.R.; Scholz, H.C.; et al. The Yersinia pseudotuberculosis complex: Characterization and delineation of a new species, Yersinia wautersii. Int. J. Med. Microbiol. 2014, 304, 452-463. [CrossRef]

54. Thal, E.; Knapp, W. A revised antigenic scheme of Yersinia pseudotuberculosis. Symp. Ser. Immunobiol. Standard. 1971, 13, $219-222$.

55. Bogdanovich, T.; Carniel, E.; Fukushima, H.; Skurnik, M. Use of O-antigen gene cluster-specific PCRs for the identification and O-genotyping of Yersinia pseudotuberculosis and Yersinia pestis. J. Clin. Microbiol. 2003, 41, 5103-5112. [CrossRef] [PubMed]

56. Duan, R.; Liang, J.; Shi, G.; Cui, Z.; Hai, R.; Wang, P.; Xiao, Y.; Li, K.; Qiu, H.; Gu, W.; et al. Homology analysis of pathogenic Yersinia: Yersinia enterocolitica, Yersinia pseudotuberculosis, and Yersinia pestis based on multilocus sequence typing. J. Clin. Microbiol. 2014, 52, 20-29. [CrossRef] [PubMed]

57. Skurnik, M.; Peippo, A.; Ervela, E. Characterization of the O-antigen gene clusters of Yersinia pseudotuberculosis and the cryptic O-antigen gene cluster of Yersinia pestis shows that the plague bacillus is most closely related to and has evolved from $Y$. pseudotuberculosis serotype O:1b. Mol. Microbiol. 2000, 37, 316-330. [CrossRef] [PubMed]

58. Matsura, M. Structural modifications of bacterial lipopolysaccharide that facilitate Gram-negative bacteria evasion of host innate immunity. Front. Immunol. 2013, 4, 109. [CrossRef] [PubMed]

59. Porat, R.; McCabe, W.R.; Brubaker, R.R. Lipopolysaccharide associated resistance to killing of yersiniae by complement. J. Endotoxin Res. 1995, 2, 91-97. [CrossRef]

60. Karlyshev, A.V.; Oyston, P.C.; Williams, K.; Clark, G.C.; Titball, R.W.; Winzeler, E.A.; Wren, B.W. Application of high-density arraybased signature-tagged mutagenesis to discover novel Yersinia virulence-associated genes. Infect. Immun. 2001, 69, 7810-7819. [CrossRef]

61. Mecsas, J.; Bilis, I.; Falkow, S. Identification of attenuated Yersinia pseudotuberculosis strains and characterization of an orogastric infection in BALB/c mice on day 5 postinfection by signature-tagged mutagenesis. Infect. Immun. 2001, 69, 2779-2787. [CrossRef]

62. Flashner, Y.; Mamroud, E.; Tidhar, A.; Ber, R.; Aftalion, M.; Gur, D.; Lazar, S.; Zvi, A.; Bino, T.; Ariel, N.; et al. Generation of Yersinia pestis attenuated strains by signature-tagged mutagenesis in search of novel vaccine candidates. Infect. Immun. 2004, 72, 908-915. [CrossRef]

63. Wang, X.; Quinn, P.J. Lipopolysaccharide: Biosynthetic pathway and structure modification. Prog. Lipid Res. 2010, 49, 97-107. [CrossRef]

64. Akira, S.; Hemmi, H. Recognition of pathogen-associated molecular patterns by TLR family. Immunol Lett. 2003, 85, 85-95. [CrossRef]

65. Weiss, J.; Barker, J. Diverse pro-inflammatory endotoxin recognition systems of mammalian innate immunity. F1000 Res. 2018, 7, 516. [CrossRef] [PubMed]

66. Kawahara, K.; Tsukano, H.; Watanabe, H.; Lindner, B.; Matsuura, M. Modification of the structure and activity of lipid A in Yersinia pestis lipopolysaccharide by growth temperature. Infect. Immun. 2002, 70, 4092-4098. [CrossRef]

67. Prior, J.L.; Hitchen, P.G.; Williamson, D.E.; Reason, A.J.; Morris, H.R.; Dell, A.; Wren, B.W.; Titball, R.W. Characterization of the lipopolysaccharide of Yersinia pestis. Microb. Pathog. 2001, 30, 49-57. [CrossRef]

68. Korneev, K.V.; Kondakova, A.N.; Arbatsky, N.P.; Novototskaya-Vlasova, K.A.; Rivkina, E.M.; Anisimov, A.P.; Kruglov, A.A.; Kuprash, D.V.; Nedospasov, S.A.; Knirel, Y.A.; et al. Distinct biological activity of lipopolysaccharides with different lipid A acylation status from mutant strains of Yersinia pestis and some members of genus Psychrobacter. Biochemistry 2014, 79, 1333-1338. [CrossRef]

69. Steinstraesser, L.; Kraneburg, U.; Jacobsen, F.; Al-Benna, S. Host defense peptides and their antimicrobial-immunomodulatory duality. Immunobiology 2011, 216, 322-333. [CrossRef] [PubMed]

70. Gunn, J.S.; Lim, K.B.; Krueger, J.; Kim, K.; Guo, L.; Hackett, M.; Miller, S.I. PmrA-PmrB-regulated genes necessary for 4-aminoarabinose lipid A modification and polymyxin resistance. Mol. Microbiol. 1998, 27, 1171-1182. [CrossRef] [PubMed] 
71. Holst, O. The structures of core regions from enterobacterial lipopolysaccharides-an update. FEMS Microbiol. Lett. 2007, 271, 3-11. [CrossRef]

72. Klein, K.A.; Fukuto, H.S.; Pelletier, M.; Romanov, G.; Grabenstein, J.P.; Palmer, L.E.; Ernst, R.; Bliska, J.B. A transposon site. hybridization screen identifies galU and wecBC as important for. survival of Yersinia pestis in murine macrophages. J. Bacteriol. 2012, 194, 653-662. [CrossRef]

73. Mathew, B.; Aoyagi, K.L.; Fisher, M.A. Yersinia pestis lipopolysaccharide remodeling confers resistance to a Xenopsylla cheopis cecropin. bioRxiv 2021, 7, 2536-2545. [CrossRef]

74. Knirel, Y.A.; Anisimov, A.P. Lipopolysaccharide of Yersinia pestis, the Cause of Plague: Structure, Genetics, Biological Properties. Acta Nat. 2012, 4, 46-58. [CrossRef]

75. Band, V.I.; Weiss, D.S. Mechanisms of Antimicrobial Peptide Resistance in Gram-Negative Bacteria. Antibiotics 2015, 4, 18-41. [CrossRef] [PubMed]

76. Shaikhutdinova, R.Z.; Ivanov, S.A.; Dentovskaya, S.V.; Titareva, G.M.; Knirel, Y.A. Characterization of a transposon Tn5-generated mutant of Yersinia pestis defective in lipooligosaccharide biosynthesis. Biochemistry 2019, 84, 398-406. [CrossRef] [PubMed]

77. Fukuto, H.S.; Vadyvaloo, V.; McPhee, J.B.; Poinar, H.N.; Holmes, E.C.; Bliska, J.B. A single amino acid change in the response regulator PhoP, acquired during Yersinia pestis evolution, affects PhoP target gene transcription and polymyxin B susceptibility. J. Bacteriol. 2018, 200, e00050-18. [CrossRef] [PubMed]

78. Aoyagi, K.L.; Brooks, B.D.; Bearden, S.W.; Montenieri, J.A.; Gage, K.L.; Fisher, M.A. LPS modification promotes maintenance of Yersinia pestis in fleas. Microbiology 2015, 161, 628-638. [CrossRef] [PubMed]

79. Guo, J.; Nair, M.K.; Galván, E.M.; Liu, S.L.; Schifferli, D.M. Tn5AraOut mutagenesis for the identification of Yersinia pestis genes involved in resistance towards cationic antimicrobial peptides. Microb. Pathog. 2011, 51, 121-132. [CrossRef]

80. Felek, S.; Muszyński, A.; Carlson, R.W.; Tsang, T.M.; Hinnebusch, B.J.; Krukonis, E.S. Phosphoglucomutase of Yersinia pestis is required for autoaggregation and polymyxin B resistance. Infect. Immun. 2010, 78, 1163-1175. [CrossRef] [PubMed]

81. Geng, J.; Song, Y.; Yang, L.; Feng, Y.; Qiu, Y.; Li, G.; Guo, J.; Bi, Y.; Qu, Y.; Wang, W.; et al. Involvement of the post-transcriptional regulator Hfq in Yersinia pestis virulence. PLoS ONE 2009, 4, e6213. [CrossRef]

82. Nishino, K.; Hsu, F.F.; Turk, J.; Cromie, M.J.; Wösten, M.M.; Groisman, E.A. Identification of the lipopolysaccharide modifications controlled by the Salmonella PmrA/PmrB system mediating resistance to Fe(III) and Al(III). Mol. Microbiol. 2006, 61, 645-654. [CrossRef]

83. Anisimov, A.P.; Dentovskaya, S.V.; Titareva, G.M.; Bakhteeva, I.V.; Shaikhutdinova, R.Z.; Balakhonov, S.V.; Lindner, B.; Kocharova, N.A.; Senchenkova, S.N.; Holst, O.; et al. Intraspecies and temperature-dependent variations in susceptibility of Yersinia pestis to the bactericidal action of serum and to polymyxin B. Infect. Immun. 2005, 73, 7324-7331. [CrossRef]

84. Bengoechea, J.A.; Lindner, B.; Seydel, U.; Ramón, D.; Ignacio, M. Yersinia pseudotuberculosis and Yersinia pestis are more resistant to bactericidal cationic peptides than Yersinia enterocolitica. Microbiology 1998, 144, 1509-1515. [CrossRef] [PubMed]

85. Zurabyan, V.A.; Pavlovich, N.V.; Makarovskaya, L.N.; Ryzhkova, V.V.; Bugaeva, O.K. In vitro influence of biologically active factors of microorganisms on antibiotic susceptibility of Yersinia pestis. Antibiot. Khimioter. 1997, 42, 22-25. [PubMed]

86. Abdelbaqi, S.; Deslouches, B.; Steckbeck, J.; Montelaro, R.; Reed, D.S. Novel engineered cationic antimicrobial peptides display broad-spectrum activity against Francisella tularensis, Yersinia pestis and Burkholderia pseudomallei. J. Med. Microbiol. 2016, 65, 188-194. [CrossRef] [PubMed]

87. Pouillot, F.; Derbise, A.; Kukkonen, M.; Foulon, J.; Korhonen, T.K.; Carniel, E. Evaluation of O-antigen inactivation on Pla activity and virulence of Yersinia pseudotuberculosis harbouring the pPla plasmid. Microbiology 2005, 151, 3759-3768. [CrossRef]

88. Chandler, C.E.; Harberts, E.M.; Pelletier, M.R.; Thaipisuttikul, I.; Jones, J.W.; Hajjar, A.M.; Sahl, J.W.; Goodlett, D.R.; Pride, A.C.; Rasko, D.A.; et al. Early evolutionary loss of the lipid A modifying enzyme PagP resulting in innate immune evasion in Yersinia pestis. Proc. Natl. Acad. Sci. USA 2020, 117, 22984-22991. [CrossRef] [PubMed]

89. Telepnev, M.V.; Klimpel, G.R.; Haithcoat, J.; Knirel, Y.A.; Anisimov, A.P.; Motin, V.L. Tetraacylated lipopolysaccharide of Yersinia pestis can inhibit multiple Toll-like receptor-mediated signaling pathways in human dendritic cells. J. Infect. Dis. 2009, 200, 1694-1702, Erratum in J. Infect. Dis. 2010, 201, 314. [CrossRef]

90. Skurnik, M. Molecular genetics, biochemistry and biological role of Yersinia lipopolysaccharide. Adv. Exp. Med. Biol. 2003, 529, 187-197. [CrossRef]

91. Mikula, K.M.; Kolodziejczyk, R.; Goldman, A. Yersinia infection tools-characterization of structure and function of adhesins. Front. Cell. Infect. Microbiol. 2013, 2, 169. [CrossRef]

92. Eren, E.; van den Berg, B. Structural basis for activation of an integral membrane protease by lipopolysaccharide. J. Biol. Chem. 2012, 287, 23971-23976. [CrossRef]

93. Yang, K.; He, Y.; Park, C.G.; Kang, Y.S.; Zhang, P.; Han, Y.; Cui, Y.; Bulgheresi, S.; Anisimov, A.P.; Dentovskaya, S.V.; et al. Yersinia pestis Interacts With SIGNR1 (CD209b) for Promoting Host Dissemination and Infection. Front. Immunol. 2019, 10, 96. [CrossRef]

94. He, Y.X.; Ye, C.L.; Zhang, P.; Li, Q.; Park, C.G.; Yang, K.; Jiang, L.Y.; Lv, Y.; Ying, X.L.; Ding, H.H.; et al. Yersinia pseudotuberculosis Exploits CD209 Receptors for Promoting Host Dissemination and Infection. Infect. Immun. 2018, 87, e00654-18. [CrossRef]

95. Zhang, P.; Skurnik, M.; Zhang, S.S.; Schwartz, O.; Kalyanasundaram, R.; Bulgheresi, S.; He, J.J.; Klena, J.D.; Hinnebusch, B.J.; Chen, T. Human dendritic cell-specific intercellular adhesion molecule-grabbing nonintegrin (CD209) is a receptor for Yersinia pestis that promotes phagocytosis by dendritic cells. Infect. Immun. 2008, 76, 2070-2079. [CrossRef] [PubMed] 
96. Strittmatter, W.; Galanos, C. Characterization of protein co-extracted together with LPS in Escherichia coli, Salmonella minnesota and Yersinia enterocolitica. Microb. Pathog. 1987, 2, 29-36. [CrossRef]

97. Vakorina, T.I.; Novikova, O.D.; Krasikova, I.N.; Naberezhnykh, G.N.; Solov'eva, T.F.; Ovodov, Y.S. Interaction of porin from Yersinia pseudotuberculosis with different structural forms of endogenous lipopolysaccharide. Biochemistry 2003, 68, 976-983. [CrossRef]

98. Confer, A.W.; Ayalew, S. The OmpA family of proteins: Roles in bacterial pathogenesis and immunity. Vet. Microbiol. 2013, 163, 207-222. [CrossRef]

99. Bartra, S.S.; Gong, X.; Lorica, C.D.; Jain, C.; Nair, M.K.; Schifferli, D.; Qian, L.; Li, Z.; Plano, G.V.; Schesser, K. The outer membrane protein A (OmpA) of Yersinia pestis promotes intracellular survival and virulence in mice. Microb. Pathog. 2012, 52, 41-46. [CrossRef] [PubMed]

100. Krukonis, E.S.; Thomson, J.J. Complement evasion mechanisms of the systemic pathogens Yersiniae and Salmonellae. FEBS Lett. 2020, 594, 2598-2620. [CrossRef] [PubMed]

101. Korhonen, T.K.; Haiko, J.; Laakkonen, L.; Järvinen, H.M.; Westerlund-Wikström, B. Fibrinolytic and coagulative activities of Yersinia pestis. Front. Cell Infect. Microbiol. 2013, 3, 35. [CrossRef] [PubMed]

102. Suomalainen, M.; Lobo, L.A.; Brandenburg, K.; Lindner, B.; Virkola, R.; Knirel, Y.A.; Anisimov, A.P.; Holst, O.; Korhonen, T.K. Temperature-induced changes in the lipopolysaccharide of Yersinia pestis affect plasminogen activation by the Pla surface protease. Infect. Immun. 2010, 78, 2644-2652. [CrossRef]

103. Kolodziejek, A.M.; Schnider, D.R.; Rohde, H.N.; Wojtowicz, A.J.; Bohach, G.A.; Minnich, S.A.; Hovde, C.J. Outer membrane protein X (Ail) contributes to Yersinia pestis virulence in pneumonic plague and its activity is dependent on the lipopolysaccharide core length. Infect. Immun. 2010, 78, 5233-5243. [CrossRef] [PubMed]

104. Singh, C.; Lee, H.; Tian, Y.; Schesser Bartra, S.; Hower, S.; Fujimoto, L.M.; Yao, Y.; Ivanov, S.A.; Shaikhutdinova, R.Z.; Anisimov, A.P.; et al. Mutually constructive roles of Ail and LPS in Yersinia pestis serum survival. Mol. Microbiol. 2020, 114, 510-520. [CrossRef] [PubMed]

105. Tsang, T.M.; Wiese, J.S.; Felek, S.; Kronshage, M.; Krukonis, E.S. Ail proteins of Yersinia pestis and Y. pseudotuberculosis have different cell binding and invasion activities. PLoS ONE 2013, 8, e83621. [CrossRef]

106. Davies, D.A.L. A specific polysaccharide of Pasteurella pestis. Biochem. J. 1956, 63, 105-116. [CrossRef]

107. Larrabee, A.R.; Marshall, J.D.; Crozier, D. Isolation of antigens of Pasteurella pestis I. Lipopolysaccharide-protein complex and R and S Antigens. J. Bacteriol. 1965, 90, 116-119. [CrossRef]

108. Byvalov, A.A.; Pautov, V.N.; Chicherin, L.V.; Lebedinskii, V.A.; Evstigneev, V.I. Effectiveness of revaccinating hamadryas baboons with NISS live dried plague vaccine and fraction I of the plague microbe. Zh. Mikrobiol. Epidemiol. Immunobiol. 1984, 4, 74-76.

109. Montminy, S.W.; Khan, N.; McGrath, S.; Walkowicz, M.J.; Sharp, F.; Conlon, J.E.; Fukase, K.; Kusumoto, S.; Sweet, C.; Miyake, K.; et al. Virulence factors of Yersinia pestis are overcome by a strong lipopolysaccharide response. Nat. Immunol. 2006, 7, 1066-1073. [CrossRef]

110. Anisimov, A.P.; Shaikhutdinova, R.Z.; Pan'kina, L.N.; Feodorova, V.A.; Savostina, E.P.; Bystrova, O.V.; Lindner, B.; Mokrievich, A.N.; Bakhteeva, I.V.; Titareva, G.M.; et al. Effect of deletion of the lpxM gene on virulence and vaccine potential of Yersinia pestis in mice. J. Med. Microbiol. 2007, 56, 443-453. [CrossRef]

111. Airhart, C.L.; Rohde, H.N.; Bohach, G.A.; Hovde, C.J.; Deobald, C.F.; Lee, S.S.; Minnich, S.A. Induction of innate immunity by lipid A mimetics increases survival from pneumonic plague. Microbiology 2008, 154, 2131-2138. [CrossRef]

112. Filippov, A.A.; Sergueev, K.V.; Nikolich, M.P. Can phage effectively treat multidrug-resistant plague? Bacteriophage 2012, 2, 186-189. [CrossRef]

113. Zhao, X.; Cui, Y.; Yan, Y.; Du, Z.; Tan, Y.; Yang, H.; Bi, Y.; Zhang, P.; Zhou, L.; Zhou, D.; et al. Outer membrane proteins ail and OmpF of Yersinia pestis are involved in the adsorption of T7-related bacteriophage Yep-phi. J. Virol. 2013, 87, 2260-2269. [CrossRef] [PubMed]

114. Derbise, A.; Carniel, E. YpfPhi: A filamentous phage acquired by Yersinia pestis. Front. Microbiol. 2014, 5, 701. [CrossRef]

115. Garcia, E.; Elliott, J.M.; Ramanculov, E.; Chain, P.S.; Chu, M.C.; Molineux, I.J. The genome sequence of Yersinia pestis bacteriophage phiA1122 reveals an intimate history with the coliphage T3 and T7 genomes. J. Bacteriol. 2003, 185, 5248-5262. [CrossRef]

116. Kiljunen, S.; Datta, N.; Dentovskaya, S.V.; Anisimov, A.P.; Knirel, Y.A.; Bengoechea, J.A.; Holst, O.; Skurnik, M. Identification of the lipopolysaccharide core of Yersinia pestis and Yersinia pseudotuberculosis as the receptor for bacteriophage phiA1122. J. Bacteriol. 2011, 193, 4963-4972. [CrossRef]

117. Schofield, D.A.; Molineux, I.J.; Westwater, C. Diagnostic bioluminescent phage for detection of Yersinia pestis. J. Clin. Microbiol. 2009, 47, 3887-3894. [CrossRef]

118. Schofield, D.A.; Molineux, I.J.; Westwater, C. Rapid identification and antibiotic susceptibility testing of Yersinia pestis using bioluminescent reporter phage. J. Microbiol Methods. 2012, 90, 80-82. [CrossRef]

119. Filippov, A.A.; Sergueev, K.V.; He, Y.; Huang, X.Z.; Gnade, B.T.; Mueller, A.J.; Fernandez-Prada, C.M.; Nikolich, M.P. Bacteriophage-resistant mutants in Yersinia pestis: Identification of phage receptors and attenuation for mice. PLoS ONE 2011, 6, e25486. [CrossRef] [PubMed]

120. Filippov, A.A.; Sergueev, K.V.; He, Y.; Nikolich, M.P. Bacteriophages capable of lysing Yersinia pestis and Yersinia pseudotuberculosis: Efficiency of plating tests and identification of receptors in Escherichia coli K-12. Adv. Exp. Med. Biol. 2012, 954, 123-134. [PubMed] 
121. Zhao, X.; Wu, W.; Qi, Z.; Cui, Y.; Yan, Y.; Guo, Z.; Wang, Z.; Wang, H.; Deng, H.; Xue, Y.; et al. The complete genome sequence and proteomics of Yersinia pestis phage Yep-phi. J. Gen. Virol. 2011, 92, 216-221. [CrossRef] [PubMed]

122. Rashid, M.H.; Revazishvili, T.; Dean, T.; Butani, A.; Verratti, K.; Bishop-Lilly, K.A.; Sozhamannan, S.; Sulakvelidze, A.; Rajanna, C. A Yersinia pestis-specific, lytic phage preparation significantly reduces viable $Y$. pestis on various hard surfaces experimentally contaminated with the bacterium. Bacteriophage 2012, 2, 168-177. [CrossRef] [PubMed]

123. Comeau, A.M.; Arbiol, C.; Krisch, H.M. Composite conserved promoter-terminator motifs (PeSLs) that mediate modular shuffling in the diverse T4-like myoviruses. Genome Biol. Evol. 2014, 6, 1611-1619. [CrossRef] [PubMed]

124. Yuan, Y.; Xi, H.; Dai, J.; Zhong, Y.; Lu, S.; Wang, T.; Yang, L.; Guan, Y.; Wang, P. The characteristics and genome analysis of the novel Y. pestis phage JC221. Virus Res. 2020, 283, 197982. [CrossRef] [PubMed]

125. Salem, M.; Pajunen, M.I.; Jun, J.W.; Skurnik, M. T4-like Bacteriophages Isolated from Pig Stools Infect Yersinia pseudotuberculosis and Yersinia pestis Using LPS and OmpF as Receptors. Viruses 2021, 13, 296. [CrossRef]

126. Laird, M.W.; Kloser, A.W.; Misra, R. Assembly of LamB and OmpF in deep rough lipopolysaccharide mutants of Escherichia coli K-12. J. Bacteriol. 1994, 176, 2259-2264. [CrossRef]

127. de Cock, H.; Tommassen, J. Lipopolysaccharides and divalent cations are involved in the formation of an assembly competent intermediate of outer-membrane protein PhoE of E. coli. EMBO J. 1996, 15, 5567-5573. [CrossRef]

128. de Cock, H.; Pasveer, M.; Tommassen, J.; Bouveret, E. Identification of phospholipids as new components that assist in the in vitro trimerization of a bacterial pore protein. Eur. J. Biochem. 2001, 268, 865-875. [CrossRef] [PubMed]

129. Bogdanov, M.; Dowhan, W. Lipid-assisted protein folding. J. Biol. Chem. 1999, 274, 36827-36830. [CrossRef]

130. Bogdanov, M. Lipid-dependent membrane protein topogenesis. Annu. Rev. Biochem. 2009, 78, 515-540. [CrossRef] 